OECD Regional Development Working

Papers 2010/1

\title{
Policies to Enhance the Physical Urban Environment for Competitiveness
}

A New Partnership between Public and Private Sectors

Tetsuya Shimomura and Tadashi Matsumoto

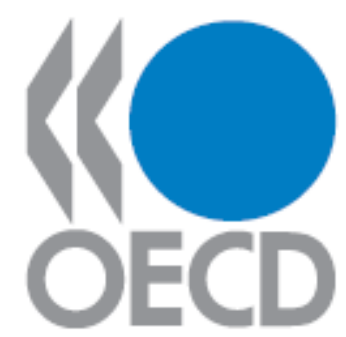

Shimomura, Tetsuya and Tadashi Matsumoto (2010), "Policies to Enhance the Physical Urban Environment for Competitiveness: A New Partnership between Public and Private Sectors", OECD Regional Development Working Papers, 2010/1, OECD Publishing, ( ) OECD. doi: $10.1787 / 5 \mathrm{kmmnd} 1 \mathrm{rst} 7 \mathrm{c}-\mathrm{en}$ 


\section{OECD REGIONAL DEVELOPMENT WORKING PAPERS}

This series is designed to make available to a wider readership selected studies on regional development issues prepared for use within the OECD. Authorship is usually collective, but principal authors are named.

The papers are generally available only in their original language English or French with a summary in the other if available.

The opinions expressed in these papers are the sole responsibility of the author(s) and do not necessarily reflect those of the OECD or the governments of its member countries.

Comment on the series is welcome, and should be sent to either gov.contact@oecd.org or the Public Governance and Territorial Development Directorate, 2, rue André Pascal, 75775 PARIS CEDEX 16, France.

OECD Regional Development Working Papers are published on www.oecd.org/gov/regional/workingpapers

Applications for permission to reproduce or translate all or part of this material should be made to: OECD Publishing, rights@oecd.org or by fax 33145249930.

(c) OECD 2010 


\section{FOREWORD}

This working paper is one in a series of OECD Working Papers on Regional Development of the OECD Public Governance and Territorial Development Directorate.

This report has been produced and co-ordinated by Tetsuya Shimomura (Senior Policy Analyst) and Tadashi Matsumoto (Senior Policy Analyst) under the supervision of Hiroshi Kobayashi (Head of the Regional Policy for Sustainable Development Division). We would like to acknowledge those who have provided valuable comments on the report, including Adam Ostry (Chair of Working Party on Territorial Policy in Urban Area), Keith Thorpe (Communities and Local Government, Government of the United Kingdom), and Juan Carlos Zentella-Gomez (Secretariat of Social Development, Government of Mexico). Special thanks are also given to Peter Howe (Newcastle City Council) and David Usher (Newcastle City Centre Partnership) for providing valuable comments and relevant background materials.

We would also like to thank the Ministry of Land, Infrastructure, Transport and Tourism of Japan for providing a financial contribution to produce this working paper.

The paper can be downloaded on the OECD website: www.oecd.org/gov/cities

Further enquiries about this work in this area should be addressed to:

Tadashi Matsumoto (tadashi.matsumoto@oecd.org) of the OECD Public Governance and Territorial Development Directorate.

Mario Pezzini, Deputy Director,

Directorate for Public Governance and Territorial Development 


\section{TABLE OF CONTENTS}

FOREWORD

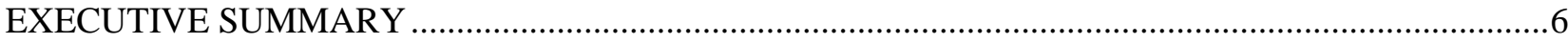

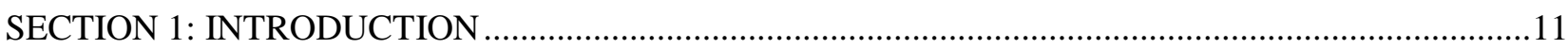

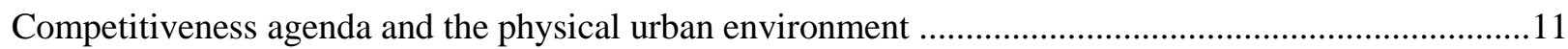

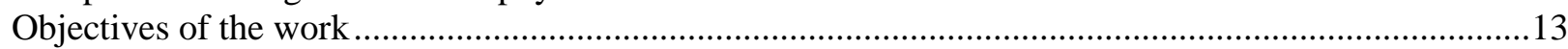

SECTION 2: THE DEFINITION AND CHARACTERISTICS OF URBAN ENVIRONMENT AND

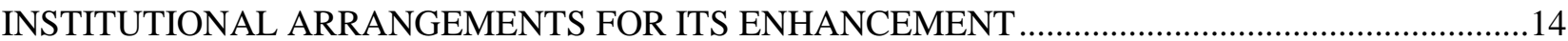

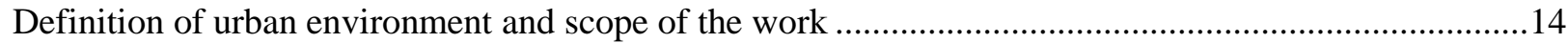

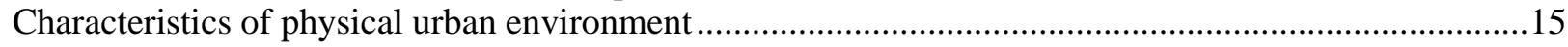

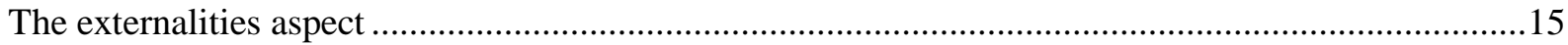

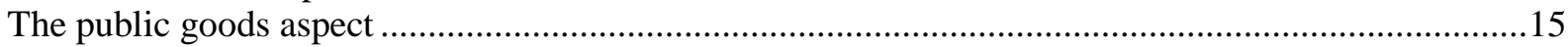

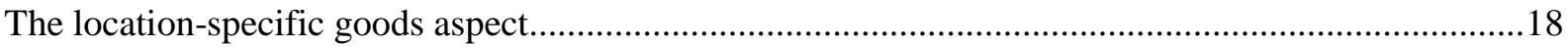

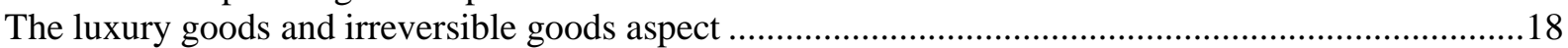

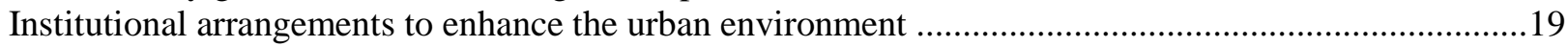

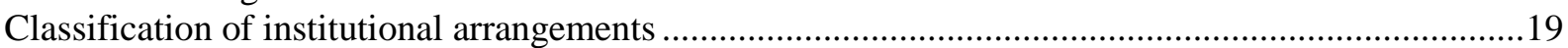

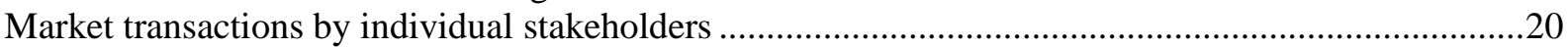

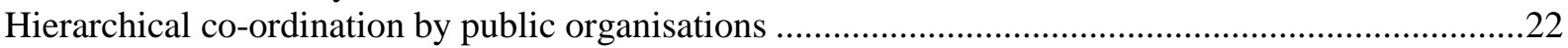

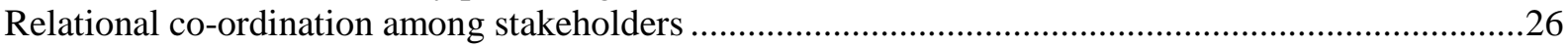

SECTION 3: A NEW PARTNERSHIP BETWEEN PUBLIC AND PRIVATE SECTOR FOR URBAN

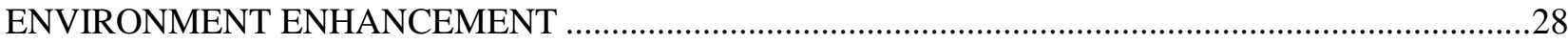

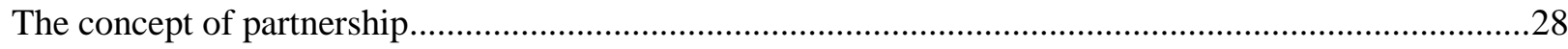

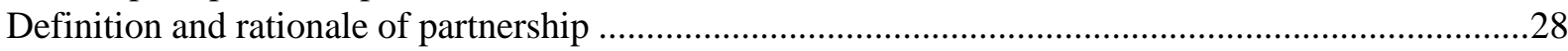

Partnership as an institutional arrangement for urban environment enhancement ................................29

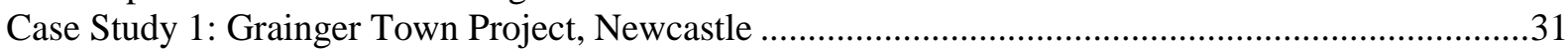

Case Study 2: Otemachi-Marunouchi-Yurakucho District, Tokyo ........................................................33

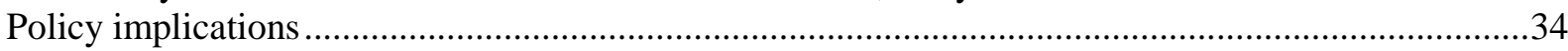

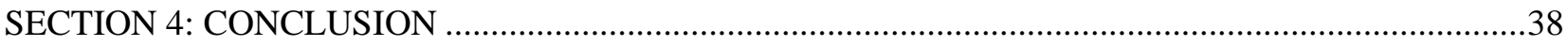

Key policy recommendations for enhancing physical urban environment .............................................38

Identifying strategic targets and sharing vision on urban environment enhancement among

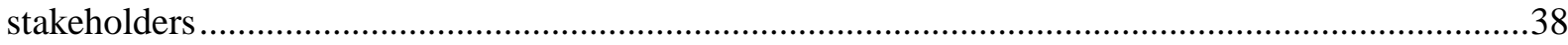

Creating critical mass to incentivise investors to contribute to urban environment enhancement..........38

Establishing area-based organisational mechanisms for urban environment enhancement ...................39

Considering self-sustaining mechanisms for long-term enhancement of the urban environment...........39

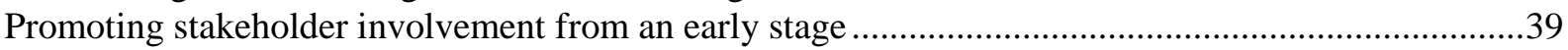

Gathering sufficient information necessary to decide the optimal level of public intervention..............40

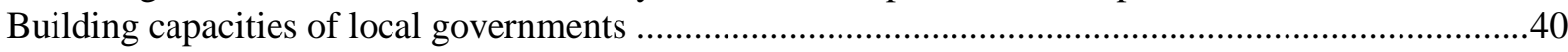

ANNEX A: MODELS TO ANALYSE INSTITUTIONAL ARRANGEMENTS FOR URBAN ENVIRONMENT ENHANCEMENT 
Transaction costs

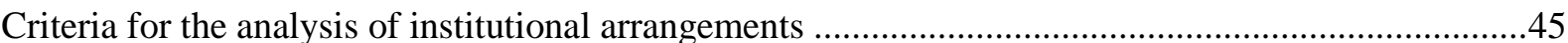

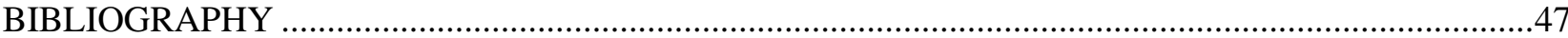

\section{Tables}

Table 2.1. Examples of monetary (economic) valuation methods

\section{Figures}

Figure 2.1. Structure of the Grainger Town Partnership..........................................................................32

Figure 2.2. Relations among organisations for the OMY district development ......................................34

Figure A1. Internalisation of externalities through voluntary transactions .............................................42

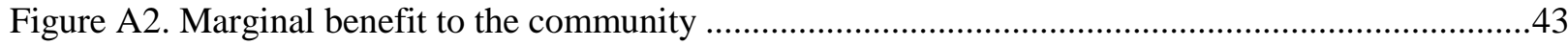

Figure A3. The effect of changes in people's preferences for the urban environment .............................44

\section{Boxes}

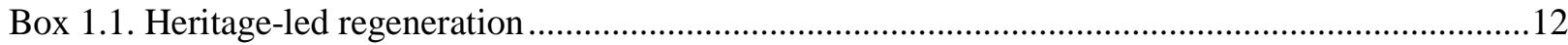

Box 1.2. Competitive European cities: Where do the core cities stand? ..............................................13

Box 2.1. Transition of policies to enhance the urban environment .......................................................14

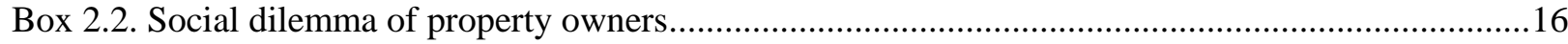

Box 2.3. Critical mass model on urban environment enhancement ....................................................17

Box 2.4. Modes of governance - market, hierarchy and network ........................................................20

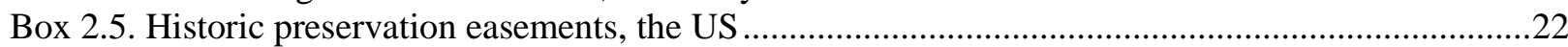

Box 2.6. Economic evaluation of landscape regulations (Japan) and street design (the UK) .................25

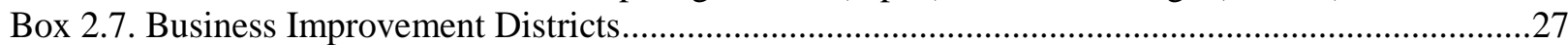

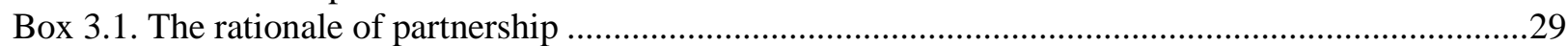

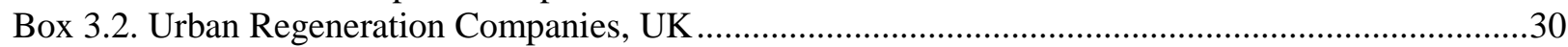

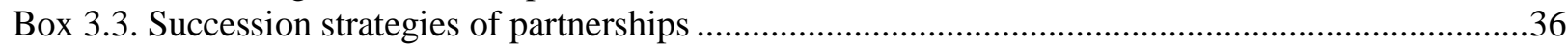




\section{EXECUTIVE SUMMARY}

\section{Introduction}

Globalisation and subsequent competition among cities have triggered a profound change in the mode of the governance of cities. It is often described as a shift from a managerial mode of governance, which had been primarily concerned with provision of social welfare services and control of private activities, to that of entrepreneurialism, strongly characterised by a pro-economic growth strategic approach. Subsequently, attractiveness has been increasingly regarded as a key factor for urban policies, since attractive cities are competitive and able to attract newly-emerging businesses and highly-skilled workforces that are the driving force in the global economy. Today, enhancing urban attractiveness is high on the agenda of urban policy in many OECD countries.

A city's attractiveness is determined by a wide range of elements. The OECD report "Competitive Cities: A New Entrepreneurial Paradigm in Spatial Development" (OECD, 2007) analysed various elements contributing to urban attractiveness (e.g. flagship redevelopment, cultural facilities, international events, etc.). Among various findings, it emphasises that it is important for a city to enhance its distinctiveness by identifying and building up urban assets that are unique to the city. In particular, many cities have recognised that attractive physical environment of cities can enhance their uniqueness and distinctiveness.

Physical urban environment, such as urban townscape, historic features and natural amenities, has several unique characteristics, including its public goods aspect. This means that it cannot be delivered by separate individual actions only. On the other hand, the elements of physical urban environment are mostly private properties and private stakeholders play an essential role in enhancing the quality. Therefore, in order to create and maintain attractive physical urban environment, it is essential to develop institutional arrangements which encourage private stakeholders to take actions towards collaborative public goals. The key concern here is how to overcome existing barriers in order to achieve attractive physical urban environment.

Recently, we observe that many cities in OECD countries have introduced area-based institutional mechanisms to enhance physical urban environment, recognising the importance of city's attractiveness. Although the past OECD works have identified physical urban environment as one of the key factors for city's attractiveness, we have not yet in depth discussed how to achieve better physical urban environment. Against this backdrop, this paper studies policy framework in order to enhance physical urban environment. After analysing the characteristics of physical urban environment and institutional arrangements to address the barriers to its enhancement, the paper then highlights recent innovative areabased partnerships with two case studies, in order to examine key factors for successful institutional arrangements.

\section{Institutional arrangements to enhance physical urban environment}

From an economics perspective, physical urban environment can be characterised by several unique features which distinguish it from ordinary goods: $i$ ) externalities, ii) public goods (free-rider issues), iii) location-specific goods, and $i v$ ) luxury and irreversible goods. Externalities and public goods aspects make 
it difficult to achieve the optimal supply level of attractive physical urban environment without some coordination mechanisms. Location-specific goods aspect implies the necessity to design institutional arrangements according to the scale of the external effects of each specific physical urban environment. Luxury and irreversible goods aspects suggest that, while people's valuation of physical urban environment could change over time, it would be difficult to restore the value once it has been eliminated.

Since these unique characteristics create certain barriers to efficient and effective provision of attractive physical urban environment, well-designed institutional arrangements are necessary to overcome the barriers. Based on institutional economics perspectives, such institutional arrangements can be roughly classified into three categories: $i$ ) stimulating market transactions by individual stakeholders (e.g. instruments to encourage transfer of property rights), $i i$ ) implementing hierarchical coordination by public organisations (e.g. regulatory instruments), and iii) promoting relational coordination among stakeholders (e.g. partnership approaches).

Each institutional arrangement has specific strengths and weaknesses. Particularly, in order to design efficient and effective policy frameworks it is important for policymakers to take into consideration various benefits and costs associated. They include: $i$ ) social benefits accruing from implementing an institutional arrangement (e.g. increases in property values of targeted areas), ii) social costs accruing from implementing an institutional arrangement (e.g. direct cost such as investment, indirect cost such as decreases in potential development rights), and iii) transaction costs of implementing an institutional arrangement (e.g. information costs, negotiation costs, enforcement costs).

\section{A new partnership between public and private sector to enhance physical urban environment}

Among different institutional arrangements described above, we observe that partnership approaches have been increasingly promoted in order to enhance physical urban environment. This trend is in line with the recent change in the mode of the governance, which aims to create economic growth through collaboration among public and private stakeholders rather than through controlling private activities by hierarchical management. Better partnership approaches could not only help coordination among stakeholders, but also produce synergetic effects by mobilising various assets and resources (e.g. human capital, knowledge and information, public funding and private capital, etc.) from one stakeholder to another.

Two major trends can be observed with regard to areas where partnership approaches have been set up. First, partnership approaches are encouraged to transform the physical urban environment and thereby reverse the economic decline of an area. This is typically found in a middle-sized city that has suffered from economic restructuring and decline. Second, partnership approaches are promoted to strengthen further the attractive physical urban environment and thereby attract more investment in an area. This phenomenon can be observed in major cities competing with other cities in the globalised economy or even competing with other areas within the city.

In order to analyse in depth partnership approaches to enhance physical urban environment, we look at two case studies which characterise these two trends, first Grainger Town Project in Newcastle, UK, and then Otemachi-Marunouchi-Yurakucho (OMY) district in Tokyo, Japan.

In the case of the Grainger Town Project, the Grainger Town Partnership made significant efforts to share the vision with all the stakeholders through various activities. It published the "Grainger Town Regeneration Strategy," which became a very influential foundation for the development of the project, identifying unique urban assets and playing a catalytic role in building consensus among stakeholders. The report led to a shift in the emphasis of the project from the narrow conservation agenda to a broader economic development approach. In addition, the commitment of public expenditure in the targeted area, 
eventually amounting to GBP 45 million, was a crucial factor in the success of the project. As the result, private sector investment reached over GPB 145 million, almost double the original target of GBP 74 million, and 121 buildings have been brought back into use, compared with a target of 70 . The economic revival of Grainger Town was also reflected in the growth of retail and office rental values. Moreover, total employment in Grainger Town grew by 14\% during the project period.

In the case of the OMY district, the establishment of the Advisory Committee on OMY Area Development enabled limited intellectual and relational resources to be strategically allocated in the enhancement of the targeted area, which led to the issuance of the City-Planning Guidelines. The CityPlanning Guidelines have played a crucial role in coordination not only among different private stakeholders but also among public and private sectors. The strategically targeted public investment such as the main street pavement for newly-invited glamorous boutiques also contributed to revitalising the entire area.

When analysing these cases, it is important to note that the strategies used in the areas are not automatically applicable to other cities. However, these examples clearly indicate the strength of partnership approaches: the two area-based partnership organisations have devoted themselves successfully to building up private investors' trust and confidence in the targeted areas and to incentivising them to make investments.

\section{Key challenges and policy recommendations to enhance physical urban environment}

Based on the discussions above, we have identified three key challenges for policymakers in order to enhance physical urban environment: $i$ ) how to give stakeholders incentive to contribute to the enhancement of physical urban environment; $i$ ) how to mobilise urban assets and resources strategically and achieve synergetic effects to the enhancement of physical urban environment; and iii) how to reduce social costs associated with public intervention to enhance physical urban environment. Following the short description of each challenge, we propose our policy recommendations.

\section{Challenge one: How to give stakeholders incentive to contribute to the enhancement of physical urban environment?}

Identifying unique urban assets and sharing a vision of enhancing physical urban environment among stakeholders

In many cases, physical urban environment is characterised as a public good. The free-rider phenomenon associated with public goods prevents each individual stakeholder from contributing to a collective action to enhance it, even though such collective action could maximise the total benefits. The first step to avoid this situation would be to clearly show all the stakeholders in a targeted area the social benefits of enhancing the physical urban environment and to give them incentive to make contributions to the collective action. To achieve this, it is crucial to identify the unique urban assets of the area and share a vision of enhancing the physical urban environment among stakeholders.

Area-based organisations (e.g. urban regeneration partnerships, urban community organisations) would be among key contributors to such policies, because they represent local demands for better physical urban environment and dedicated to its enhancement. Experts who raise awareness of the value of the physical urban environment would also contribute. A public sector could play an important role in encouraging these organisations and experts by supporting them. 


\section{Creating a 'critical mass' by giving investors incentives to enhance physical urban environment}

As physical urban environment is composed not only of public realms but also of private properties, collaborative institutional arrangements between public and private sectors (e.g. property owners and investors) are an essential factor to enhance physical urban environment.

In particular, because long-term private investment is crucial to building up and maintaining momentum for enhancement of physical urban environment, a public sector has to play a significant role at an initial stage in giving private investors incentives to invest, such as intensive public investments in a targeted area. By delivering a clear visual message to investors, they can see the benefit of their investments. In other words it is key to establish a 'critical mass' by which private investors have confidence in the future of the area and are attracted to make investments.

\section{Challenge two: How to mobilise urban assets and resources strategically and achieve synergetic effects to the enhancement of physical urban environment?}

\section{Establishing an area-based organisational arrangement}

Given that resources are usually limited, strategic allocation of human and financial resources to a targeted area is important for maximising the value from inputs. An organisational arrangement, such as an area-based organisation dedicated to enhancing the physical urban environment of a targeted area, is crucial as a strategic vehicle to allocate the limited resources.

Establishing an area-based organisational arrangement would help facilitating collective decisionmaking and reducing transaction costs associated with it. While such an arrangement requires stakeholders' own institutional costs, a public sector can play an important role in reducing them through various types of support (e.g. standardising the formation of such entities, financing the activities).

Considering self-sustaining mechanisms for maintaining and further enhancing physical urban environment

While it is a crucial role for a public sector to create a 'critical mass' at an initial stage by giving private investors incentives to invest, the public involvement as a catalyst is usually for a short-term. In order to maintain the momentum generated and further enhance the attractive physical urban environment of the area, it is essential to develop a self-sustaining mechanism. While financing is obviously one of the essential issues, a public sector could play a supportive role in promoting such a self-sustaining mechanism through, for instance, establishing an organisational scheme which ensures area-based independent financial resources (e.g. Business Improvement Districts in the US and other countries).

\section{Challenge three: How to reduce social costs associated with public intervention to enhance physical urban environment?}

\section{Promoting stakeholder participation in the decision-making of public intervention}

A hierarchical public intervention (e.g. regulatory instruments) is often necessary to enhance physical urban environment. However, without stakeholders' understanding on its objectives and possible effects, it would lose their support and could lead to the high enforcement costs. To avoid this situation and enhance effective and efficient implementation, it is essential to promote stakeholder participation in the decisionmaking process.

In order to promote active participation, it would be important to establish a decision-making system which ensures to take stakeholders' opinion into consideration (e.g. the right to propose a statutory 
development plan), and to promote area-based organisational arrangements among public and private stakeholders.

In addition, in order to make stakeholder participation effective, it is important for each participant to clearly recognise the value of information (e.g. the unique value of urban townscape of an area) at their disposal. In this regard, area-based organisations and experts who are engaged in raising awareness of stakeholders about such information would play a key role. A public sector's effort to support them would be another key.

Gathering information to decide the optimal level of public intervention

When designing and implementing a hierarchical public intervention, one of the greatest challenges for policymakers is to decide the level of intervention to private market. Gathering necessary and sufficient information is crucial in order to achieve the optimal level of intervention.

One way to gather information is to promote stakeholder participation in the decision-making process. Another way is to use evaluation methods in order to estimate the social benefits and costs of public intervention. It could help policymakers aware of the benefits and costs of policy instruments, which may otherwise have been overlooked. 


\section{SECTION 1: INTRODUCTION}

\section{Competitiveness agenda and the physical urban environment}

Globalisation and the subsequent intensification of competition among cities have triggered the profound change in the mode of the governance of cities. This is often described as a shift from a managerial mode of governance, which is primarily concerned with provision of social welfare services and control of private activities, to that of entrepreneurialism, strongly characterised by a pro-economic growth strategic approach (OECD, 2007). This change has been most evident in the urban policies that have been increasingly adopted by many cities, particularly by old industrial cities that have experienced an unprecedented magnitude of industrial decline. The goal of those policies is to make the cities attractive locations for newly-emerging knowledge-based businesses and workers that are the driving force in the current globalised economy. The central idea is to present the city as an attractive place to visit, live, work and invest in the global market where mobile capital and knowledge workers find their destinations. These promotional measures adopted by cities for economic regeneration can be viewed as efforts to enhance "city attractiveness". Recognising the importance of attractiveness for urban competitiveness, the OECD organised the "International Symposium on Enhancing City Attractiveness for the Future" in Nagoya, Japan in 2005, and published "Competitive Cities: A New Entrepreneurial Paradigm in Spatial Development" in 2007. These works identified various elements determining urban attractiveness as well as challenges cities face in pursuing policies to enhance urban attractiveness.

One of the significant factors determining urban attractiveness is the physical urban environment. It provides the tangible basis for city attractiveness, not only giving people the basic functionality of a city but also making a great contribution to the character, diversity and sense of identity of the area. The physical urban environment is also expected to play an important role in city marketing by providing a material expression of the city image that city branding attempts to create. Thus a wide range of attempts have been made to enhance the city's image and restructure its economy by improving the physical urban environment in many cities. Especially in former industrial cities, which declined steadily throughout the latter half of the $20^{\text {th }}$ century, the physical renovation of the environment played a vital role in enhancing the declining image of the area. Some successful flagship redevelopments have produced remarkable results, demonstrated by impressive visual impacts that have materialised on sites which used to be rundown areas with a concentration of economic, social and environmental problems. In addition to innovative flagship redevelopment, strategic urban regeneration utilising unique urban assets such as cultural and historic assets has also been pursued to enhance the distinctiveness and thereby strengthen urban attractiveness and competitiveness. One of the greatest challenges for policymakers to enhance the physical urban environment is now how to strengthen the uniqueness by identifying untapped distinctive urban assets and mobilising them to maximise their potential contribution to urban attractiveness and competitiveness.

The physical urban environment which enhances the distinctiveness and uniqueness of a city is composed of various elements, such as distinctive urban townscape, the presence of historic features, high quality public realms, and natural amenities. These features have been recognised by many cities as important factors to differentiate themselves from other cities in attracting private investment. Although the importance of distinctiveness varies depending on the investment sector, if all the primary considerations are strong, it is the issue of distinctiveness that in many cases will strongly influence a decision to invest in one place over another. For instance, if a city is competing with other alternative places which all offer the basic business requirements (e.g. site availability, accessibility, etc.), 
distinctiveness could become a critical factor for firms in their investment decisions (Chester City Council 2002).

The physical urban environment that distinguishes one city from others is not only a significant asset for tourism, as in many historic cities, but also an important factor for urban competitiveness as a whole. People are increasingly attracted by the quality of place such as its unique urban character, along with the diversity and amenities the area possesses. Attracting people by enhancing the physical urban environment leads to revitalising economic activities such as retail shopping in the area. In many countries, enhancing the unique character of an area, by for instance designating historic districts and using historic assets in regeneration and retail development, has become an important tool to promote economic development in urban areas (Listokin et al, 1998; Leichenko et al., 2001; Coulson et al., 2004), (see Box 1.1).

\section{Box 1.1. Heritage-led regeneration}

In many countries, the cultural and historical environment has increasingly been recognised as an important contributor to enhancement of the urban environment and regeneration initiatives through its catalytic role in revitalising a city's economy as well as reinforcing a sense of place and community. In many cases historic buildings play a key role in regeneration projects through adding quality and place distinctiveness to the area.

For example, the UK Government has highlighted the importance of the role of historic environment in urban regeneration (ODPM, 2004a), and the English Heritage, the UK Government's statutory adviser on the historic environment, has produced several guidelines concerning the effective use of historic buildings in urban regeneration and retail development (English Heritage, 2005, 2006). A wide range of funding schemes are utilised to support and promote heritage-led regeneration, such as the Regional Development Agencies (RDAs) funding programmes (e.g. the RDAs are able to use their "Single Pot" resources to determine and address their own priorities, including support for the heritage-led regeneration) and Townscape Heritage Initiative led by the Heritage Lottery Fund.

In Japan, the Government introduced new legislation to maintain and enhance the historic environment in May 2008 (Act on Maintenance and Enhancement of Historic Environment) with effective horizontal co-ordination across ministries (Ministry of Land, Infrastructure, Transport and Tourism, Cultural Affairs Agency, and Ministry of Agriculture, Forestry and Fisheries), aiming at attracting visitors and revitalising local economies as well as building up residents' respect for their communities. This legislation enables not only flexible land use regulations but also strategic allocation of financial resources to enhance the distinctive urban historic environment.

There is a strong economic case for utilising the historic environment as a catalytic contributor in urban regeneration. The benefits of such utilisation relate not only to the individual buildings, but also to the wider area and community. For example, the heritage-led regeneration of the Lace Market in Nottingham, which brought 100 buildings into use, created 3500 jobs and 210 new businesses. Another award-winning heritage-led regeneration, Granger Town Project in Newcastle, brought 121 buildings into use and created 1506 direct jobs (as well as 800 indirect jobs) and 286 new businesses (English Heritage, 2006). In Japan, through regeneration efforts to improve unique townscape by utilising urban historical assets, many cities have succeeded in attracting more visitors than before (e.g. from 2.7 million visitors in 1986 to 7.6 million in 2005 in Otaru City, from 1.0 million visitors in 1984 to 5.5 million in 2006 in Kawagoe City) (MLIT, 2008). As such, a successful regeneration scheme tapping under-utilised urban historical assets can not only contribute to conservation objectives but also boost the economy of the city as a whole.

On the other hand, there are several negative effects of heritage-led regeneration. Gentrification of an older heritage area can sometimes result in the local population and small businesses being displaced by wealthier groups and enterprises moving in, attracted by the improved environment. A key challenge is to ensure that heritage-led regeneration addresses local needs, and appeals to the most suitable range of uses and potential occupiers, subject to commercial realities and physical constraints. Ways to address this concern include: planning for the provision of affordable housing and affordable workspace in the re-development strategy so that the result is a more mixed community; and establishing "cultural and creative" quarters in older historic areas with the aim of helping small creative business to thrive and grow in the area. 
The importance of the physical urban environment for uniqueness and competitiveness has been recognised at the national and international level as well. For example, research conducted by the UK government looking at urban competitiveness of European core cities found that quality of life, such as good environment, distinctive architecture and access to natural amenities, is becoming an increasingly important factor in attracting skilled workers (see Box 2). Another report by the UK government argues that these features will be crucial to maintaining British competitiveness in the fast-moving international economic environment (DCMS, 2004). The EU member states also recognised in the European Spatial Development Perspective (European Commission, 1999) that past urban development measures have often diminished the historic fabric of many cities and eroded their identity, and concluded that this not only has a negative effect on the quality of life but also has an economic impact due to loss of attractiveness and reduced investment, employment and municipal financial resources. The importance of the physical urban environment such as distinctive urban landscape is also recognised in Asian countries. For instance, the Japanese government enacted the "Landscape Law" in 2004, recognising that quality urban landscape enhances a city's capability for global and regional competitiveness.

\section{Box 1.2. Competitive European cities: Where do the core cities stand?}

A recent study in the UK defined and measured urban competitiveness in terms of six characteristics (economic diversity, skilled workforce, connectivity, strategic capacity to implement long-term development strategies, innovation in firms and organisation, quality of life). It found that a skilled workforce is critical to the economic performance of cities, and that quality of life is becoming an increasingly important factor in attracting skilled workers. Cities with the assets of good environment, distinctive architectures, access to natural amenities, etc., are attempting to preserve and improve them (e.g. Munich, Lyon and Barcelona). Those which are not so well blessed with such assets are attempting to create them in their cities (e.g. Dortmund and Rotterdam).

Source : ODPM (2004b)

\section{Objectives of the work}

While the importance of attractiveness for urban competitiveness and the significance of the physical urban environment that strengthens distinctiveness and uniqueness were recognised in past OECD works, an analytical study on mechanisms for efficient and effective provision of such environment as well as a comparative study on practical policies and governance for its enhancement have not yet been produced. From an economics perspective, an attractive urban environment has several unique characteristics, including a public goods aspect that creates certain barriers to its efficient supply through voluntary transactions in the market. In order to design and implement effective policies and governance, it is crucial to better understand these characteristics and to analyse policy direction to overcome these barriers. As another example, while an attractive urban environment as a whole has a public goods characteristic, elements of the urban environment include not only typical public goods such as public realms but also private properties the quality of which private stakeholders play an essential role in enhancing. To create and maintain attractive urban environment, it is key to develop institutional arrangements among private and public stakeholders which encourage private individuals by means of sufficient incentives to take actions towards collaborative public goals. These institutional arrangements for attractive urban environment have not yet been discussed in-depth in past OECD works.

Against this backdrop, this paper will examine recent innovative policy frameworks to actualise good physical urban environment. After analysing the characteristics of physical urban environment and institutional arrangements to address the barriers to its enhancement, it will highlight recent innovative institutional frameworks, notably area-based partnerships, which aim to enhance the physical urban environment contributing to uniqueness and competitiveness through collaborative mode of governance, with in-depth case studies to examine key factors for successful institutional arrangements. 


\section{SECTION 2: THE DEFINITION AND CHARACTERISTICS OF URBAN ENVIRONMENT AND INSTITUTIONAL ARRANGEMENTS FOR ITS ENHANCEMENT}

\section{Definition of urban environment and scope of the work}

Urban environment is related to a wide range of issues and can be interpreted in a number of ways. According to the scale of the effects on environment, they range from regional-scale issues such as air and water pollution to neighbourhood-scale issues such as townscape and historical amenities. Moreover, they can be classified in terms of the emphasis of the urban environment policy, namely whether the policy is intended to reduce negative aspects of urban environment (e.g. pollution, congestion, etc.) or enhance some positive aspects (e.g. attractive townscape, historical and natural amenities, etc.). According to the challenges each city faced at the time, the emphasis of the policy to enhance the urban environment has been shifted (see Box 2.1).

\section{Box 2.1. Transition of policies to enhance the urban environment}

Enhancing urban environment has been a continuous issue for modern urban policy over the past two centuries, and changes of emphasis can be observed in several phases. In the latter part of the $19^{\text {th }}$ century after the Industrial Revolution much interest centred on public health in overcrowded urban areas. Local authorities sought to improve the urban environment by such measures as sewage control and clean water supply to reduce public health problems such as the spread of disease and infection. This trend has continued throughout the $20^{\text {th }}$ century, leading to such policies as clean air legislation and waste management systems.

In the late $19^{\text {th }}$ and early $20^{\text {th }}$ century a new social movement, which sought to tackle the problems stemming from the extreme overcrowding of early industrial cities, emerged, calling for a new balance between the city and the surrounding countryside in which populations were decentralised into carefully planned new communities in the countryside (e.g. garden cities). Although this movement emerged before automobile use became widespread, it led to a huge wave of new development in suburban areas against the backdrop of rapid growth of automobile use. This led to another set of environmental problems, namely those related to low-density suburban sprawl and inner city decline.

As personal income rises and leisure time becomes common in modern society, concerns about immediate human needs give way to other interests, such as the quality of the built environment (e.g. townscape, historical heritage, etc.) and the presence of nature (waterfronts, green areas, etc.), namely, "urban amenities", which not only give people aesthetic pleasure but also make a great contribution to the character, diversity and sense of identity of the urban areas. Both individuals and businesses are now leaving the city as the perceived quality of life deteriorates, accelerating the decline of the central city and flight into the suburbs or other cities. More recently, since the impact of globalisation and the emergence of knowledge-based economies have become apparent, one of the most pressing challenges for urban policy planners has become how to enhance urban attractiveness and thereby attract the highly skilled and creative workforce required by new economic sectors. Urban amenities and attractiveness are now regarded as a key asset for the competitiveness of cities.

As mentioned in the introduction, the attractiveness of a city has been increasingly recognised as one of the important factors to maintain and strengthen its competitiveness in an era of global competition and knowledge-based economies. Among various elements determining a city's attractiveness, an attractive physical urban environment, such as attractive townscape, the presence of historic features and natural amenities, is now widely recognised as an important factor in strengthening distinctiveness and uniqueness of a city. These features attract not only tourists who contribute to economic vitalisation in the city but also people who live and work in the city. People are now increasingly attracted not only by the basic functionality of the city but also the quality of the place itself, such as unique urban character, diversity and sense of identity of the area. Attracting people by enhancing physical urban environment is now one of the 
important strategies for private investors in urban development, especially commercial and business development.

Recognising the importance of good physical urban environment such as attractive townscape and historical and natural amenities for competitiveness, this paper will focus on policy framework to enhance it.

\section{Characteristics of physical urban environment}

From an economics perspective, an attractive physical urban environment can be characterised by several unique features which distinguish it from ordinary goods. The first step in designing and implementing effective and efficient policies and governance should be to better understand the nature of the physical urban environment as well as barriers that governments must address. The major characteristics of the physical urban environment are as follows:

\section{The externalities aspect}

Externalities might be the most important aspect of physical urban environment issues. Cities are concentrations of people and their activities, and the essence of urban activities is the presence, for better and for worse, of many other people and activities (Kanemoto, 1980). Transactions of ordinary private goods which are bought and sold by individuals at a market price always involve flows in two directions: a payment is made whenever a good is transferred. However, some goods are transferred from one party to another without payment. Externalities arise when production or consumption by one party affects the production or utility of another party without compensation. When externalities decrease the production or utility of the affected party, it is called negative externalities (external costs or diseconomies). A typical example of negative externalities is that of a factory that dumps untreated waste water into a nearby river, thus polluting the water for downstream users. On the other hand, when externalities increase the production or utility of the affected party, it is called positive externalities (external benefits or economies). Elements of attractive urban environment, such as well-co-ordinated townscape, historic features and natural amenities, are considered to be examples of positive externalities.

The distinction between positive and negative externalities does not depend upon the technical characteristics of the effects being considered. Rather it depends upon a social judgement as to what are the responsibilities or duties associated with property rights. Hodge (1994) explains that this can be portrayed in terms of a reference point with respect to environmental quality. This point defines the particular allocation of individual property rights and hence the level of responsibility which property owners are required to assume. Where property owners fail to achieve the reference point environmental quality, this would be regarded as negative externalities. Where property owners achieve an environmental quality in excess of this standard, they would be regarded as generating positive externalities. This point is not immutable. It is subject to movement in response to changes in social attitudes towards the rights and duties associated with property use and these are in turn influenced by a wide range of economic and social forces.

\section{The public goods aspect}

As with many other environmental goods, most of the physical urban environment is non-excludable, which means it is impossible (or prohibitively expensive) to exclude a person from consuming it. For example, it might be difficult to charge for the consumption of urban amenities, such as distinctive townscape, without specifying the beneficiaries.

The characteristic of non-excludability leads to a free rider phenomenon. The provision to one person of the good which has non-excludable characteristics entails its provision to other persons. Therefore 
potential consumers will lose the incentive to state their true willingness to pay since they can gamble on the good being provided to others who express some willingness to pay. Those who gain the benefits from consuming the good without paying for it are known as free riders. Because of the free rider phenomenon, the market would fail to provide an efficient outcome (see Box 2.2). Free riding is a ubiquitous phenomenon in the world of goods the consumption of which produces external benefits. ${ }^{1}$

\section{Box 2.2. Social dilemma of property owners ${ }^{2}$}

The free-rider phenomenon causes public goods to be provided at a sub-optimal level. Assume one property owner $(A)$ is thinking of 1 unit of investment in improving his property. If all the owners of adjacent properties do likewise, the value of all properties would increase, say 2 units, because of the external economies of their improvement to each other's property value. Therefore the net benefit of each owner would be 1 unit (the higher left of the 'individual benefit' matrix). If owner A receives the external economy without investing for his property's improvement, his net benefit would be 2 units (1 unit of benefit without paying 1 unit of cost) as described in the lower left of the matrix. If owner $A$ invests 1 unit in improving his property but the other owners do not invest likewise, his net benefit would be -1 unit (the higher right of the matrix). Under the circumstances, the rational choice (i.e. dominant strategy) of owner A is not to invest. In other words, the rational strategy of individual property owners is to be a freerider.

The rational choice for society as a whole, however, is different. Though it is difficult to calculate the amount of social benefits, we assume that social benefit is the sum of individual benefits. If there are 100 owners in a society and all of them invest 1 unit in improving their properties, the social benefit would be 100 units. However, if all the owners take their individually rational choice (i.e. free-rider option), the social benefit would be 0 . Hence, the rational choice for society is to make all the property owners invest.

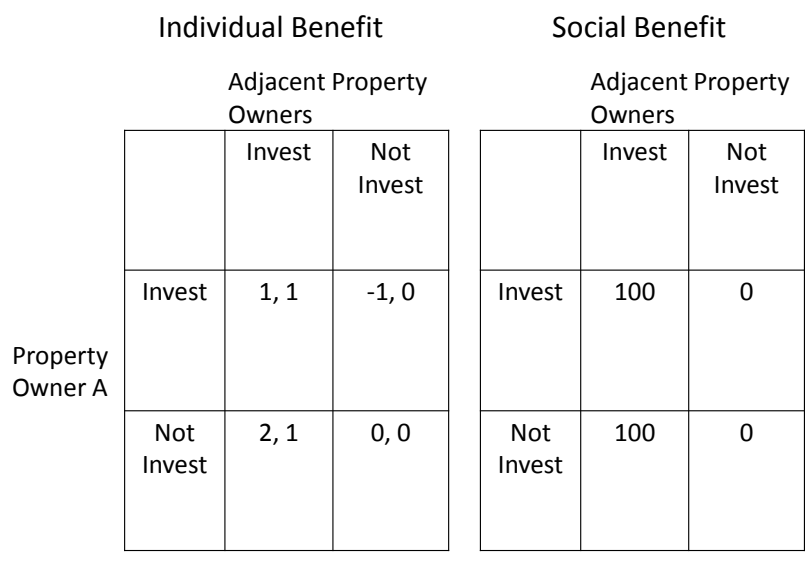

Source: OECD (1999).

In order to avoid the free rider phenomenon and achieve an efficient provision of quality urban environment, it is essential for all the stakeholders to share the information on the benefits accruing from the environment and to ensure their commitment to contribute to its enhancement.

The free rider phenomenon occurs because an individual stakeholder may not have an incentive to contribute to the enhancement of the physical urban environment. If he can benefit from contributing to its

1. In terms of non-excludability, public goods are identical to the concept of external economy (Shibata et al., 1988).

2. Davis et al. (1961) and Ashworth (2002) similarly discussed the property owner's dilemma based on game theory. 
enhancement in a situation where a certain level of other stakeholders are also contributing, and if his decision whether to contribute or not depends on the level of other stakeholders' contributions, then the "critical mass model" might be applicable in explaining the phenomena related to urban environment enhancement (see Box 2.3). ${ }^{3}$

\section{Box 2.3. Critical mass model on urban environment enhancement}

A critical mass model is widely used to understand and explain a variety of social phenomena, in which the way people's behaviour depends on how many are expected to behave a particular way, or how much they are expected to behave.

The figure shows the application of the critical mass model for the situation in which an individual investor's decision on contribution to the enhancement of a certain area depends on how much the area's urban environment is expected to be enhanced by other investors. It is assumed that enhancement of the urban environment is proportional to the number of investors who make investments contributing to its enhancement, the level of which can be measures by the percentage of investors. The horizontal axis indicates how much the urban environment is expected to be enhanced by investors, and the vertical axis indicates the cumulative percentage of investors who will make actual investments according to the expected enhancement of the urban environment.

The 'critical' level of urban environment enhancement, according to which one investor decides to make his investment contributing to additional environment enhancement, might differ from another's. If such critical levels cluster around some average ( $\beta$ in the figure) and taper off in both directions, the cumulative percentage of investors who will make investments forms an S-shaped curve as shown in the figure.

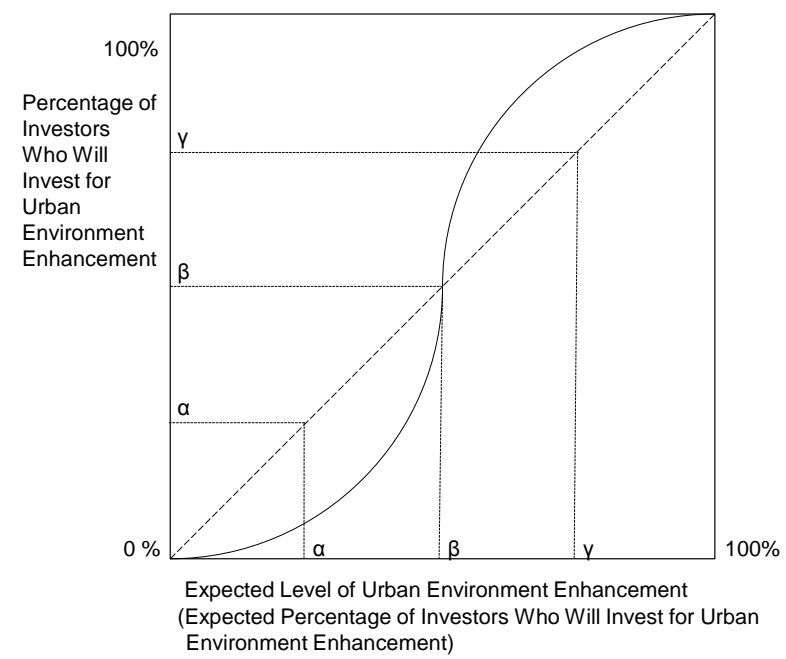

The figure shows that, when the expected level of urban environment enhancement is a (alpha) percent, there are less than a (alpha) percent of investors who will invest. On the other hand, when the expected level of urban environment enhancement is $b$ (beta) percent, there are more than $b$ (beta) percent of investors who will invest.

Thus there are two stable equilibriums in this case. One is with $100 \%$ expected and $100 \%$ investments, the other is with none expected and no investments. Any percentage less than $\beta$ will contain some who will decide not to invest, lowering the level of investments so that others also decide not to invest, successively until nobody's left. Any percentage in excess of $\beta$ will attract more, who raise the level of enhancement and attract more, until $100 \%$ are investing. If exactly $\beta \%$ is expected and $\beta \%$ invest, any small divergence upward or downward will attract a few more or repel a few, and the percentage will grown to $100 \%$ or decline to zero. Thus $\beta \%$ is an unstable equilibrium, that is called a 'tipping point' or 'critical mass'. If the level of investment surpasses that point, self-sustaining enhancement of the urban environment would be achieved.

3. Schelling (1978) provided one of the earliest and best-know discussions of the critical-mass model as a general model applicable to a variety of social phenomena. 
Based on this assumption, in order to incentivise stakeholders and to achieve self-sustaining enhancement of the urban environment as a whole, it is key to create a 'critical mass'. One of the challenges for the public sector to enhance the physical urban environment is how to create such a critical mass in close collaboration with private stakeholders such as property owners and investors.

\section{The location-specific goods aspect}

While most ordinary goods are available in homogeneous units at a price which is independent of location, (i.e. not location-specific), consumption of the physical urban environment can be changed only by moving to another location. (i.e. location-specific) (Diamond et al., 1982). All physical urban environments have their own unique aspects deriving from their particular locations.

This characteristic implies that the external effects of physical urban environment are confined to a certain location. In other words, the degree of "non-excludability," which is one public goods characteristic, varies according to the types of the physical urban environment in question. The scale of the external effects could range from individual level (e.g. adjacent lands), neighbourhood level to city and regional level. Thus the institutional arrangements should be designed according to the scale of its external effect. For instance, while the external effect of the neighbourhood-level townscape could be confined to a certain area much smaller than the whole city area, that of the landscape related to view or perspective could be broader than one city area. According to the scale of the external effect of the objective to be achieved, there should be different decision-making systems and implementation mechanisms. ${ }^{4}$

\section{The luxury goods and irreversible goods aspect}

Attractive environment including attractive physical environment such as historic and natural amenities has characteristics similar to luxury goods, which means the marginal valuation of these goods increases with various factors such as income. People with more income tend to be more strongly attracted by an attractive urban environment. ${ }^{5}$ For example, with the increase of personal income and leisure time, people's consumption behaviour is changing from going to a commercial area just to shop for daily needs to going there to consume the quality of the place such as unique character, diversity and sense of identity of the area. Thus attracting people by creating high-quality physical urban environment is now becoming one of the important strategies for private investors in commercial development.

Moreover, in most cases, it is impossible or prohibitively difficult to restore the value of physical urban environment once it has been demolished. Because the value of the physical urban environment can vary over time as people's preferences for it change with various factors including income increases, it could be possible that certain environments are underestimated and demolished, though their unique value could be recognised by people in the future. This implies the importance of raising awareness of people about the unique value of the physical urban environment.

4. The location-specific aspects of the urban environment are also related to so-called 'lock-in' problems of investments in its enhancement (see Annex A). Because of this characteristic, investment by each individual stakeholder for its enhancement is meaningful only in the location. In other words, the investment is 'locked-in' the area. Thus the investor may have suboptimal incentives to make locationspecific investments, because there is a possibility that the investments cannot be fully recouped in certain situations (e.g. other investors do not make sufficient investments contributing to enhancement of the area's environment).

5. According to an amenity-based theory of location by income, the relative location of different income groups depends on the spatial pattern of urban amenities such as historical and natural amenities (Brueckner et al., 1999) When the city centre has a strong amenity advantage, the rich are likely to be attracted to central locations. 


\section{Institutional arrangements to enhance the urban environment}

The unique characteristics of attractive urban environment which create certain barriers to its efficient and effective provision necessitate well-designed institutional arrangements to overcome these barriers. Such institutional arrangements can vary from direct public intervention into private activities to facilitating voluntary transactions through market mechanisms. Because of the profound change in the mode of urban governance, which was caused by globalisation and the subsequent intensification of intercity competition as mentioned in section one, institutional arrangements adopted by national and local governments tend to place great emphasis on the role of market mechanisms as well as wider participation in hierarchical intervention. Recently, a new tendency towards other modes of governance such as collaborative governance or partnerships is emerging as an alternative institutional arrangement.

While the range of institutional arrangements which are applicable for urban environment enhancement is wide, each institution has specific strengths and weaknesses. In order for policymakers to design effective policy instruments, it is important not to narrow the range of available institutional options either to market mechanisms, hierarchical intervention or others, but to develop the advantages of each institutional arrangement and to adopt appropriate options according to the local and historical context of the city. To do so, better understanding the nature and characteristics of each institutional option is crucial. In this sub-section we overview specific institutional arrangements applicable for urban environment enhancement (i.e. market transactions by individual stakeholders, hierarchical co-ordination by public organisations, and relational co-ordination by stakeholders) following the general classification of alternative institutional arrangements.

\section{Classification of institutional arrangements}

Attempts to differentiate alternative institutional arrangements from an economics perspective often emphasise Coase's and Williamson's analysis of markets and hierarchies as distinct governance mechanisms associated with specific types of transaction costs, which has led to the establishment of new branches of economics such as transaction cost economics and new institutional economics (Coase, 1937; Williamsons, 1985). They assume that the choice of one governance structure over another depends on the nature of the transaction and the costs that result from it. If the transaction costs associated with one governance structure are less than those of another structure, the former will become dominant (see Annex A).

Early contributions to the transaction costs literature argued for a dichotomy between markets and hierarchies, with intermediate forms of organisation being seen as inherently unstable. Latterly this view has been modified, with the suggestion that intermediate forms are sustainable. This modification has added a 'third category', which places more emphasis on interactive relations between actors. Thus different triads of terms have emerged: markets, hierarchies and networks (Thompson et al. 1991); markets, politics and solidarity (Mayntz 1993); markets, bureaucracies and clans (Ouchi 1991); price, authority and trust (Bradach and Eccles 1991); market, state and community (Streek and Schmitter 1985). Although there are differences of emphases in these analyses, three ideal types of governance structures have emerged (see Box 2.4). 


\section{Box 2.4. Modes of governance - market, hierarchy and network}

A 'market mode of governance' revolves around contractual relationships over property rights. Price mechanisms are the means by which these relationships are mediated and where conflicts emerge there may be haggling or recourse to law in order to determine the liabilities of the parties involved. Markets provide a high degree of flexibility to actors in determining their willingness to form alliances, although the competitive nature of the environment and the parties' underlying suspicion may limit the degree of commitment to any collaborative venture. Essentially, actors prefer to be independent and will choose to collaborate only when they see particular advantages to themselves.

The 'hierarchical mode of governance' overcomes, in theory at least, the problems of co-ordination and collaboration found in the market place. The imposition of an authoritative integrating and supervisory structure enables bureaucratic routines to be established. Co-ordination can be undertaken by administrative fiat, and the employment relationships pertaining within the organisation encourage at least a certain level of commitment by staff. The cost, however, is a reduction in flexibility and innovation because of a tendency to formalisation and routinisation.

The 'network mode of governance' arises from a view that actors are able to identify complementary interests. The development of interdependent relationships based on trust, loyalty and reciprocity enables collaborative activity to be developed and maintained. Being voluntary, networks maintain the loyalty of members over the longer term. Conflicts are resolved within the network on the basis of members' reputational concerns.

Source : Lowndes and Skelcher (1998)

There have also been various attempts to apply the idea of transaction cost theory and the new institutional economics to further understanding of efficiency and effectiveness of alternative modes of institutional arrangements to solve externality and public good problems in the realm of land use planning (Ellickson, 1973; Alexander, 2001; Webster, 2003; Needham et al., 2004; Kim, 2005; Needham, 2006; Buitelaar, 2007; Buitelaar et al., 2007; Segeren et al., 2007; Geuting, 2007,) (see Annex I). Although it should be borne in mind that a particular set of institutional arrangements may be associated with a variety of modes of governance, we roughly classify institutional arrangements to enhance the urban environment into three categories: market transactions by individual stakeholders, hierarchical co-ordination by public organisations, and a third category such as relational co-ordination among stakeholders. ${ }^{6}$ Here it would be noteworthy that the borders between these three are becoming vague. For example, as for hierarchical coordination such as regulations, wider participation has been increasingly promoted in its decision-making process, which implies a shift of emphasis from rigid hierarchy to more flexible relational co-ordination.

\section{Market transactions by individual stakeholders}

One of the most decentralised ways to internalise externalities would be voluntary transactions by individuals through the market where people exchange rights freely and voluntarily. According to the Coase theorem, externalities can be internalised through voluntary transactions by individual parties under several assumptions (i.e. the property rights are well defined and enforceable, there are no transaction costs including negotiation costs, information costs, and other costs in exchanging property rights, etc.), since the producer and consumer of the externality have a market incentive to negotiate a mutually beneficial

6. In addition to the institutional arrangements mentioned here, there would be other options to enhance the urban environment. For example, informal social norms (e.g. morals, manners, social sanctions, etc.) have played an important role in maintaining the beautiful landscape in many historic cities. Moreover, private laws such as nuisance laws are applied in many countries to reduce negative external effects (i.e. nuisance) from one property to another by holding the property owner carrying out the damaging activity responsible for any loss (i.e. the person suffering the loss could ask for an injunction or for damages). Though we do not discuss these other options, it does not mean a downgrading of their importance. 
trade (see Annex A). For instance, a property owner could buy his neighbour's property in the market to internalise the external effects over their properties. In certain situations the voluntary exchange of property rights through the market could contribute to increasing the net social benefits without large transaction costs.

\section{Total transfer of property rights (merger)}

A merger is effected when a property owner is prompted to buy his neighbour's property in fee simple absolute. If there are no barriers such as described below, this outcome is likely where the transaction costs of acquisition are less than the costs of bargaining for a more limited exchange of rights.

Although the merger can be used as a device to internalise positive/negative externalities through market mechanisms, there are several barriers to this option. First, capital markets are imperfect and thus borrowing enough funds to make such a transaction is often difficult (i.e. financing problems). Second, because it may be difficult to identify the stakeholders (i.e. providers and beneficiaries/victims of externalities), transaction costs, especially information costs associated with the identification, could be very high. In order to overcome these barriers, organisational arrangements would be crucial to make the merger options work effectively. For instance, in many countries, non-profit organisations known as "National Trusts" have purchased properties to preserve historic buildings and natural amenities (e.g. National Trust for Places of Historic Interest or Natural Beauty in the United Kingdom, National Trust for Historic Preservation in the United States, Heritage Canada Foundation in Canada, Fondo per l'Ambiente Italiano in Italy, Roma-Condesa Trust and Historic Center Trust in Mexico, etc.).

Governments play a key role in stimulating this type of market transaction by for instance providing financial support to such non-profit organisations. In some cases governments may purchase properties themselves in the name of beneficiaries where the external effects of the properties are of interest to many citizens.

\section{Partial transfer of property rights}

Merger means the transfer of full ownership of the property. If the exchange is confined to that of full ownership of the property, it could lead to an inefficient outcome because one has to buy full ownership of the property even though he benefits from only a portion of the property. ${ }^{7}$

In some countries, land ownership is considered a "bundle of rights", some components of which can be treated separately (Renard, 2007). If the bundle of property rights can be split up and a separate right can be traded, a market for the right could be created. One example of a separate and tradable right is easements. ${ }^{8}$ An easement is an interest in land less than full ownership. An owner of a positive easement has the right to make some active use of the property subject to the easement while the owner of a negative easement (a restrictive easement) has the right to prevent the owner of the underlying property from engaging in specified uses of it. In the United States, for example, easements are widely used for various environmental purposes such as natural resource protection, farmland preservation, and historic preservation (Strong, 1983), and promoted by governments by for instance providing economic incentives such as tax deductions (see Box 2.5).

7. In the model mentioned in Annex I, if the initial property rights are assigned to the developer and the exchange is limited to total transfer of property rights, the community has only two options: to buy the full ownership of the developer's property or to do nothing.

8. Rights in land can be divided in at least three ways - spatially (e.g. horizontally and vertically), temporally (e.g. leasehold), and according to use (e.g. easements) (Evan Stake, 2000). 


\section{Box 2.5. Historic preservation easements, the US}

A historic preservation easement is a voluntary legal agreement made between a property owner and a qualified easement holding organisation to protect a significant historic property, landscape or archaeological site. Each easement is tailored to the individual needs and requirements set forth by the property owner and agreed upon by the accepting organisation. The structure to be protected by the easement need not be the entire building. Only the façade can be preserved by the easement. Moreover, under the Internal Revenue Service's (IRS) Qualified Conservation Contribution, the owner of qualified real property can receive income tax deductions equivalent to the value of the rights given away to a qualified charitable or governmental organisation.

An easement is a particularly useful historic preservation tool in several respects. First, it allows an individual to retain private ownership of the property and obtain potential financial benefits. Second, an easement binds not only the current owner, but future owners as well, ensuring that the property will be maintained and preserved by future owners. Third, easements are tailored to meet the needs of the property owner, the individual resource, and the mission of the protecting organisation. Thus an easement provides the owner with a flexible tool with which to preserve the property for future generations.

Source: US Department of the Interior (2003).

\section{Costs associated with market transaction}

In the Coase theorem, besides the well-defined property rights assumptions, it is assumed that property rights are transferable from one party to another and enforceable without any transaction costs. The real world, however, differs from that assumed in the theorem in that there are a wide range of transaction costs in exchanging and enforcing property rights (Ellickson, 1973; Fischel, 1985; Lai, 1994; Sorensen, 1994; Cooter, 1997). Such costs include information costs, negotiation costs and enforcement costs (see Annex A). Because of the specific characteristics of the urban environment, the costs associated with market transactions could be prohibitive and prevent the creation and maintenance of an attractive urban environment, which requires other institutional arrangements such as hierarchical co-ordination.

\section{Hierarchical co-ordination by public organisations}

A typical form of hierarchical co-ordination for enhancing the urban environment is regulations of private activities by public bodies. Governments can use authority without incorporating voluntary transactions of private stakeholders.

A land-use regulation, such as zoning, development control and design review, is widely used in many countries to remedy externalities and achieve various policy goals including creation and maintenance of quality urban environment (Fischel, 1985, 1999; Duerksen, 1986; Mills et al., 1994; Punter et al., 1997; Duerksen et al., 1999; Nasar et al., 1999; Cullingworth et al., 2003; Harvey et al., 2004; Cullingworth et al., 2006). Enhancing the physical urban environment has been one of the priorities in national and local planning policies including regulatory measures in many OECD countries. Especially when the number of stakeholders is large and the transaction costs accruing from reaching and enforcing the agreement are high, this type of instrument can play a significant role.

With regards to the transaction costs, one of the advantages of the regulatory instruments implemented by governments would be the relatively low negotiation costs, which could be prohibitively high in voluntary transactions. However, the enforcement costs could be high according to the enforceability of the regulation as well as the governance structure of public agencies responsible for administrating the regulation. Moreover, the information costs might be still so high that the assignment of property rights by this institutional arrangement might not be optimal in terms of the net total benefits. 
Therefore in order to make regulatory instruments work efficiently and effectively, it would be crucial to reduce the enforcement costs and the information costs as much as possible.

\section{Promotion of stakeholder participation in the decision-making process}

While policy instruments such as regulations are indispensable to enhance the distinctiveness and attractiveness of a city, implementing these policy instruments without stakeholders' understanding their objectives and possible effects would discourage them to support the policies and could lead to high enforcement costs. To avoid this situation and enforce the policies efficiently and effectively, it is essential to promote stakeholder participation in the decision-making process of the policy instruments.

There is a wide range of participation schemes in the public decision making process ranging from public hearings to direct involvement in the process of policy decision making. In many countries, participation of some kind is guaranteed by laws. For example, the Federal Building Code of Germany (Baugesetzbuch) stipulates that the public shall be informed at the earliest possible stage of drafting a landuse plan about the aims of planning, different solutions, probable impact of the scheme, etc., as well as that the public may offer suggestions to a draft land-use plan during its public display. In Japan a new city planning system was recently introduced which enables stakeholders such as property owners to propose a spatial plan to local governments. This system is expected to encourage stakeholders' willingness to participate in the planning decision-making process.

A precondition for effective participation would be that each participant clearly evaluates the information at their disposal. It is possible that even though a party has easier access to information than other parties, it might not recognise the importance of the information. For example, it often happens that citizens do not recognise the unique value of their living environment but suddenly realise it just after a development demolishes the unique value of that environment. As mentioned above, because the physical urban environment is sometimes characterised by its irreversibility, it is important to raise awareness of parties about their environment and motivate them to take into account its unique value. In this regard, experts in various fields such as architecture, planning, landscape, history, environment, etc. should play a key role in disseminating information among various parties and raise their awareness. For instance, there are a large number of organisations which aim to raise awareness of the uniqueness and importance of cultural heritage, including international non-profit organisations such as the International Council on Monuments and Sites (ICOMOS), the International Committee for the Documentation and Conservation of Monuments and Sites of the Modern Movement (DoCoMoMo), etc. Government support for these organisations and experts would be a key in promoting participation.

\section{Gathering information necessary to decide the optimal level of public intervention}

Public interventions by governments such as implementing regulations would mean deciding a desirable level of resource allocation (e.g. design of buildings) not through voluntary transactions but through a governmental process and to assign rights and obligations to each party according to that level. Because the information costs to decide the optimal level of intervention might be high, it is possible that the level decided through a governmental process might be a suboptimal one. Therefore one of the greatest challenges for policymakers would be to what extent governments should intervene in private market activities (e.g. the nature and degree of regulation).

\section{Stakeholder participation as a means to gather information}

Gathering information to decide the optimal level of public intervention is crucial when designing and implementing various policy instruments. One way to collect such information would be to promote stakeholder participation in the decision-making process. In general stakeholder participation could 
contribute to communicating information from the parties who have sufficient information to the parties who do not. In the case of implementing public policies, participation would, as mentioned above, not only reduce the enforcement costs by decreasing stakeholders' disincentives to support public policies but also help policymakers gather necessary information when designing the public intervention.

\section{Valuation of social benefits and costs}

Though participation is one of the crucial factors in gathering information from stakeholders, it would not be sufficient in deciding the optimal level of government intervention. Because participants might take into account only the benefits/costs to themselves without considering those to other parties, it might be difficult to compare various alternative levels of intervention and select the optimal one only with the information gathered through participation.

One of the criteria in considering the desirability of a government's intervention level would be to estimate the social benefits and costs accruing from the intervention and to compare them so that the net social benefits could be maximised. While the social benefits of the intervention would be positive externalities increased by the intervention (or negative externalities decreased by the intervention), the social costs would include not only direct costs (e.g. increases in construction costs) but also indirect costs such as opportunity costs (e.g. decreases in potential development rights). Though the costs could be measured relatively easily, it is significantly difficult to measure the benefits because urban environment is a non-market good, which means that there are no market mechanisms by which people's willingness to pay for the good can be reliably revealed.

In broad terms, there are two approaches to measure the value of physical urban environment: nonmonetary approaches and monetary (economic) approaches. A multi-criteria evaluation method is one of the non-monetary approaches useful to policymakers (DTLR, 2000). It involves various stakeholders and enables an overall evaluation of preferences on the basis of the demands expressed by stakeholders. Design Quality Indicators (DQI) and Value in Design (VALID) are both examples of the most common techniques used in the UK to compare various values by weighting and scoring.

As for monetary approaches, there is a wide range of techniques to place monetary values on nontraded environmental benefits. Even though these have been widely applied in the natural environment (Pearce, 1989, 2000; Turner et al., 1993; Field et al., 2006), they are also broadly applicable to the assessment of the benefits of physical urban environment such as townscape and historical features as well as related policy evaluation (OECD, 2000; Gao et al., 2001, 2007; Abelson et al., 2001, Leichenko et al., 2001; Izumi, 2002; Scottish Enterprise, 2002; Navrud et al., 2002; Coulson et al., 2004; EFTEC, 2005; Mason, 2005; Ryan et al., 2005; Lehtovuori et al., 2007). The valuation methods can be classified according to whether they seek to place a value on the good indirectly by using prices from a related market which already exists (revealed preference approaches), or directly by asking respondents their willingness to pay for an improvement or their willingness to accept a degradation (stated preference approaches) (Brooks et al., 1998). The former includes the Hedonic Pricing Method (HPM) and the Travel Cost Method (TCM), while the latter includes the Contingent Valuation Method (CVM) and the Choice Modelling (CM) (see Table 2.1). 
Table 2.1. Examples of monetary (economic) valuation methods

\begin{tabular}{|l|l|l|}
\hline & \multicolumn{1}{|c|}{ Strengths } & \multicolumn{1}{c|}{ Weaknesses } \\
\hline $\begin{array}{l}\text { Hedonic Pricing } \\
\text { Method (HPM) }\end{array}$ & $\begin{array}{l}\text { can measure individual effects of } \\
\text { various factors } \\
\text { uses objective data such as land prices }\end{array}$ & $\begin{array}{l}\text { cannot measure the non-use value } \\
\text { requires large data sets }\end{array}$ \\
\hline $\begin{array}{l}\text { Contingent Valuation } \\
\text { Method (CVM) }\end{array}$ & $\begin{array}{l}\text { can measure not only the use value but } \\
\text { also the non-use value }\end{array}$ & $\begin{array}{l}\text { cannot measure individual effects of each } \\
\text { factor }\end{array}$ \\
$\begin{array}{l}\text { Choice Modelling (CM) } \\
\text { (Conjoint Analysis, } \\
\text { etc.) }\end{array}$ & $\begin{array}{l}\text { can measure not only the use value but } \\
\text { also the non-use value } \\
\text { about their willingness to pay }\end{array}$ & $\begin{array}{l}\text { requires a survey to ask a variety of people } \\
\text { about their willingness to pay }\end{array}$ \\
\hline $\begin{array}{l}\text { Travel Cost Method } \\
\text { (TCM) }\end{array}$ & $\begin{array}{l}\text { can measure individual effects of } \\
\text { various factors }\end{array}$ & cannot measure the non-use value \\
\hline
\end{tabular}

Economic evaluations are still imprecise, and they generally require a large amount of transaction costs (e.g. expensive, time-consuming). Therefore it is important to consider the trade-off between the benefits and costs of exercising the evaluations. However, they can help make policymakers aware of a social value that may previously have been overlooked. Indeed, economic evaluations of urban amenities such as quality urban landscape and historic features have recently been conducted by governments or their agencies in some countries for better policy design (see Box 2.6).

\section{Box 2.6. Economic evaluation of landscape regulations (Japan) and street design (the UK)}

In Japan, the Council for the Promotion of Regulatory Reform, an advisory body to the Prime Minister, announced a Three-Year Plan for the Promotion of Regulatory Reform in 2006. The Plan suggests "a method should be considered to evaluate both the benefits and costs of landscape enhancement so that the regulation to enhance landscape does not lead to excessive restrictions on developments in urban areas". Based on this suggestion, the Ministry of Land, Infrastructure and Transport set forth two reports in 2007: Economic Evaluation of Landscape, and Methods to Evaluate Regulations to Enhance Landscape. They examined the economic evaluation methods, such as Hedonic Pricing Method and Conjoint Analysis, which enable comparative analysis of the benefits and costs of landscape regulations. The results were communicated to local governments for their information to evaluate their regulations and to promote accountability as well as consensus building with regards to the regulations.

In the UK, the Commission for Architecture and the Built Environment (CABE), the government's advisory body on architecture, urban design and public space, was set up in 1999, funded by the Department for Communities and Local Government and the Department for Culture, Media and Sport. CABE has been engaged in a wide range of activities, including a long-term research programme to investigate the value of design (CABE, 2000; CABE, 2001; Carmona et al., 2002). For instance, the "Value Mapping" project (CABE, 2006) assessed the methods available for capturing the range of values, tangible and less tangible, created by well-designed urban environment. "Paved with gold: The real value of good street design" (CABE, 2007) applied some of the methodologies identified in the Value Mapping project (e.g. revealed preferences approaches, stated preferences approaches, etc.) in a street design context, concluding that well-designed streets result in higher market prices.

\section{Costs associated with hierarchical co-ordination}

As discussed above, the hierarchical co-ordination by public organisations requires information gathering to decide the optimal level of public intervention, the costs of which could be prohibitive. Moreover, the administrative costs associated with running the hierarchical co-ordination could also be 
high, although it depends on the availability of existing public governance structures. While hierarchical co-ordination such as regulations is often effective in strengthening the unique character of the urban environment, the institutional costs associated with the mechanisms should also be taken into account when designing and implementing such arrangements.

\section{Relational co-ordination among stakeholders}

As mentioned at the beginning of this sub-section, there has recently been particular interest in a third mode of institutional arrangements, which is neither market nor hierarchy - relational co-ordination among stakeholders such as network, partnerships, and relational contracting. We observe here and in the next section several institutional arrangements, which are characterised by this type of mode of governance, to incentivise stakeholders towards collective efforts to enhance the urban environment.

\section{Contractual arrangements}

One institutional arrangement aiming to encourage stakeholders towards collective efforts is to enter into a contract which mutually binds all the stakeholders. For example, a 'covenant' is a popular instrument used in many countries (e.g. the U.S., the U.K., the Netherlands, Japan, etc.) as a collective contract to create and maintain a neighbourhood with a desired amenity.

Covenants negotiated between property owners will tend to optimise resource allocation among them. In other words, the social benefits will tend to exceed the sum of the social costs and transaction costs each agrees to bear. For example, when a real estate developer drafts covenants that will bind purchasers of his subdivision, profit maximising incentives make him draft desirable ones. His property values will rise only if the purchasers perceive that the covenants will increase the future benefits they might receive by an amount greater than the sum of their future social costs (e.g. loss of flexibility in use) and transaction costs. The developer should suggest, therefore, only those covenants that provide social benefits greater than the social costs and transaction costs (Ellickson, 1973).

\section{Organisational Arrangements}

One of the problems of covenants is the difficulty of changing the rules when conditions change unexpectedly. The alteration of conditions of a covenant normally requires unanimous written consent of all the property owners subject to the covenant, so the transaction costs of the alteration could be prohibitively high. This problem is often addressed through organisational arrangements, by which, instead of particular conditions being imposed in the deed to each property, the conditions are delegated to the organisation and the organisation can alter, usually by a supermajority rather than by unanimity, various common conditions in the neighbourhood (Fischel, 1985). For instance, a legal vehicle (e.g. non-profit organisation) can be created which owns the collective property (e.g. the shared spaces, easements on the privately owned properties, etc.) and which is managed by a committee elected by all the stakeholders.

The most typical example of an organisational arrangement in residential areas is to establish a homeowners' association. A homeowners' association (HOA) is the legal entity created for the purpose of managing a community of homes. It is given the authority to enforce rules (i.e. the covenants conditions and restrictions (CC\&Rs)) and to manage the common properties of the community. The associations can also compel homeowners to pay a share of common expenses, usually per-unit or based on square footage. The Community Association Institute (CAI) estimated that 59.5 million residents live in associationgoverned communities (including not only HOA but also condominiums, co-operatives and other planned communities) in the US in 2008.

The problems of this type of institutional arrangements are well known, and are usually discussed in the context of rich people isolating themselves. But such organisational arrangements can be used also by 
poorer people to give themselves more autonomy and to protect their neighbourhood environments. For example, "Community Land Trusts" in the U.S. are non-profit organisations that provide homeownership for underserved families by purchasing land, retaining title to the land, and selling only a ground lease interest in the home (Needham, 2006).

As for business areas, there is a frequently-used legal vehicle for maintaining and improving neighbourhood quality. These are "Business Improvement Districts (BIDs)", which were initiated in Canada, widely used in the U.S., and recently introduced in the U.K. and Germany (Symes et al., 2003; Hoyt, 2006) (see Box 2.7).

\section{Box 2.7. Business Improvement Districts}

A Business Improvement District (BID) is a public-private partnership to make improvements to urban environment in a given area. A widely applicable definition of the BID is provided by New York City's department of business services as follows: A Business Improvement District (BID) is an organising and financing mechanism used by property owners and merchants to determine the future of their retail, commercial and industrial areas. The BID is based on state and local law, which permits property owners and merchants to band together to use the city's tax collection powers to "assess" themselves. These funds are collected by the city and returned in their entirety to the BID and are used for purchasing supplemental services (e.g. maintenance, sanitation, security, promotions and special events) and capital improvements (e.g. street furniture, trees, signage, special lighting) beyond those services and improvements provided by the city. In essence, the program is one of self-help through self-taxation.

While a BID is referred to by various titles, such as special improvement district, special assessment district, business assistance district, business improvement zone, special service district, etc., what they have in common is that properties and/or businesses within a legally constituted district pay a special tax or assessment to cover the cost of providing facilities or services for which the district has a particular need.

Source : Houstoun (1997).

\section{New momentum towards relational mode of governance}

Over the past few decades, relational co-ordination among stakeholders has been paid increasing attention as an alternative mode of governance. While traditional government approaches such as hierarchical co-ordination (e.g. regulations) take for granted the interest of the private sector to invest in urban development, in areas where the private sector has no such interest, there is little left for governments to intervene for. The pro-growth approach, which has emerged against the background of economic globalisation and inter-city competition, requires an alternative institutional arrangement such as relational co-ordination or collaborative governance between the public and private stakeholders. In the next section, we analyse more deeply this new trend in urban governance for urban environment enhancement, focusing especially on partnership arrangements in urban regeneration. 


\section{SECTION 3: A NEW PARTNERSHIP BETWEEN PUBLIC AND PRIVATE SECTOR FOR URBAN ENVIRONMENT ENHANCEMENT}

As mentioned in the introduction, economic globalisation and the subsequent intensification of intercity competition have caused a profound change in the governance of cities, which has been described as a change "from managerialism to entrepreneurialism" (Harvey, 1989). In the realm of urban planning policy, such a new attitude is commonly referred to as urban entrepreneurialism, which envisages positive and strategic measures based on a pro-active approach, rather than a problem-solving one, together with new institutional structures of urban governance.

While urban entrepreneurialism took various forms in different policy contexts, it is characterised by some shared features such as pro-economic growth approach and partnerships between public and private sectors. The new approach aims to create and initiate economic growth rather than control and manage it. While traditional government intervention in urban spatial planning takes for granted the private sector's interest in investing in urban areas, in areas with scarce interest on the part of the private sector to invest there is little left to plan for. In this regard, the traditional approach to spatial development had almost been rendered powerless. It was necessary to have a totally new pro-economic growth style of policy planning.

One of the most common responses has been to develop innovative strategies for promoting economic development, which has necessitated a review of the institutional mechanisms required for effective implementation. Indeed, urban entrepreneurialism involves a fundamental change in attitude towards, and relationship with, the private sector economy, being fundamentally pro private-sector and showing a strong willingness to collaborate with it. Partnership arrangements between public and private sectors have become the predominant institutional framework within which to plan and implement urban policies.

In the context of policies to enhance the physical urban environment, this new attitude towards collaborative mode of governance is crucial. The physical urban environment is composed of various elements including not only public realms for which the public sector is mostly responsible but also private properties the quality of which the private sector, such as private owners or investors, plays an essential roles in enhancing. As mentioned in section two, one of the key factors for sustained enhancement of the urban environment is to create a critical mass which incentivises all the stakeholders to contribute to its enhancement. In order to create such a critical mass, close collaboration between public and private sectors is indispensable.

Recognising the importance of the new trend towards collaborative governance, especially the preference for the partnership mode, in policies to enhance the physical urban environment, this section analyses this mode of governance for urban environment enhancement, particularly focusing on urban regeneration partnerships.

\section{The concept of partnership}

\section{Definition and rationale of partnership}

While there is no one definition of partnership, its working definition in the context of policies to enhance the urban environment might be the mobilisation of various assets and resources (e.g. physical assets such as heritage and natural amenities, relational resources such as social networks and social capital, intellectual resources such as knowledge and information, financial resources such as public 
funding and private capital, etc.) drawn from more than one stakeholder in order to prepare and oversee an agreed upon strategy for enhancement of a defined area. ${ }^{9}$

The objectives of partnerships can evolve over time particularly as market conditions change. While various rationales of partnership can be indentified (see Box 3.1), one of the most fundamental principles of partnership is synergetic benefits for the stakeholders (i.e. more can be achieved by two or more sectors or stakeholders working together than separately). This contrasts with the traditional hierarchical approach characterised by managerialism that did not take into full consideration the advantages of collaborative interactions among stakeholders, which could not only co-ordinate externality issues between stakeholders but also contribute to growth of the total benefits for the stakeholders as a whole.

\section{Box 3.1. The rationale of partnership}

Synergy: A major justification for regeneration partnerships is the argument that together agencies can create more than they can separately. One policy-making group, for example, noted that the ideal type of partnership would achieve synergy by pooling resources and gaining co-operative action, avoiding duplication and achieving more than the sum of its parts. This viewpoint is broadly supported by many scholars and policymakers, although it is also argued that this hypothesis is subject to test.

Confidence-building and risk minimisation: In circumstances where the public sector is severely restricted in its development capacities and the development industry is in recession, confidence-building and risk minimisation become important tasks for partnerships. In all but the strongest market locations, confidence is often lacking and development finance hard to obtain. In this context, partnerships can play an important role in evolving growth strategies that provide a sense of stability and continuity in order to secure both public and private investment. Evidence from many inner-city locations suggests that the normal response is to await an upturn in the market and to leave buildings and land derelict and underused. Private developers are often wary of local authority advances and they perceive planning initiatives such as development plans as discouraging or even hostile. In that context, it is important to set up partnerships which demonstrate independence in particular from local authority.

Transformation: This process reflects the fluid approach to decision-making within partnerships and the fact that each partner attempts to influence the values and objectives of the other parties. Practitioners often comment on the difficulty of achieving a degree of consensus in the early days, as partners confront the stereotypical views they have of each other. Partnerships are arenas of bargaining and negotiation about purpose and objectives, which can transform perception of each other, build up mutual trust and facilitate consensus building.

Source : Bailey (1995), Ball et al. (2003).

\section{Partnership as an institutional arrangement for urban environment enhancement}

In a number of countries, partnership agencies or "arms-length organisations" have been set up to help co-ordination between the public and private sectors and to achieve various policy goals including urban environment enhancement. In the UK, for example, based on the recommendation of the Urban Task Force led by Lord Roger and the Urban White Paper "Our Towns and Cities: The Future", the Government launched a scheme called "Urban Regeneration Companies", recognising the importance of area-specific partnership-based arrangements between key stakeholders to mobilise various resources held by them and achieve synergetic effects in a defined area (see Box 3.2). The government of Japan has also set up a new legal framework to support area-based management operated not only by the public sector but also by residents and locally-based firms.

9. In this regard, terms such as "coalition" and "urban regime", which are often used in the academic literature, are interchangeable with partnership (Bailey, 1995). 


\section{Box 3.2. Urban Regeneration Companies, UK}

Urban Regeneration Companies (URCs) are companies limited by guarantee which are established by a local authority (or authorities), the relevant Regional Development Agency, and (usually) English Partnerships, the Government's national regeneration agency (now part of the Homes and Communities Agency). The primary role of URCs is to address significant latent development opportunities by developing and managing implementation of a plan, agreed upon by the key stakeholders following public consultation, to build business confidence and realise a collective vision for the future of the area. They are most effective in regional or sub-regional urban centres, where there is currently economic under-performance.

Following recommendations in the Urban Task Force Report, in 1999/2000 the Government supported the establishment of three pilot URCs in Liverpool, East Manchester and Sheffield. The Urban White Paper (November 2000) proposed a programme of about 12 new URCs over the next few years. Ministers confirmed in the URC Policy Stock-take in 2004 that there should be no arbitrary limit placed on the numbers of URCs, nationally or in each region. Subsequently the number of URCs increased to 22.

The URCs seek to achieve a radical physical transformation of their areas through implementation of their shared vision in a way that could not be achieved through individual ad hoc decisions. They co-ordinate investment plans from both the public and the private sectors, and attract new investment through the purposeful and imaginative promotion and regeneration of their areas.

Source : Urban Regeneration Companies, http://www.communities.gov.uk, http://www.urcs-online.co.uk.

Recently the UK Government has also highlighted the role of partnerships in promoting the successful management of town and city centres, and has shown how the development of formal partnership arrangements enables a more strategic and robust management of urban places, with the potential to make a much bigger contribution to enhancing town and city centres (DCLG, 2008). Many town and city centre partnerships have been created in response to complex and multifaceted problems, which cannot be tackled effectively by an individual or single stakeholder.

Partnership arrangements have also been encouraged in regeneration to enhance the urban environment by utilising urban historic assets (i.e. heritage-led regeneration). The UK English Heritage stresses that a successful area-based regeneration approach depends on creating the right partnership of stakeholders and ensuring that they share a common vision and understanding of the opportunities and constraints of the project. Especially in projects with a broad urban regeneration agenda not just narrowly focusing on conservation of historic environment, different stakeholders will have varying objectives ranging from the need to deliver certain socioeconomic outputs or conservation benefits, to achieving best value on a site disposal or realising a commercial return. To succeed, these objectives must be reconciled and the stakeholders must have realistic expectations, both individually and as a group (English Heritage, 2006).

While partnership approaches are pursued to enhance the urban environment in various contexts, we observe at least two major trends. First, partnership approaches are encouraged to transform the physical environment in a certain area and thereby reverse the economic and physical decline of the area. This is typical in a middle-sized city which had thrived as an industrial city in the past and has suffered from economic restructuring and decline through the closure of the industries on which the city's economy had been dependent. Second, partnership arrangements are promoted to strengthen further the attractive environment of an area in order to attract more investment into that area (competing, as it does, with other cities in the globalised economy or even competing with other areas within the city). This phenomenon can be observed in major cities, especially the capitals of countries, which are not only centres of the national economies and competing with other cities in the global arena, but also places in which various areas are 
competing with each other. In order to analyse in depth partnership arrangements to enhance the urban environment, in the following sub-sections we look at two case studies which characterise these two trends, first Grainger Town Project and then Otemachi-Marunouchi-Yurakucho district, each of which is acclaimed as best practices in terms of urban environment enhancement as well as partnership arrangements. ${ }^{10}$

\section{Case Study 1: Grainger Town Project, Newcastle}

The Grainger Town Project was established in 1997 to promote and support the comprehensive regeneration of the historic centre of Newcastle upon Tyne. A substantial part of the area was built by the developer Richard Grainger in the 1830s and 1840s during the Industrial Revolution and much of the impressive 'Tyneside Classical' architecture has survived. There are also mediaeval churches, a varied mix of old and new buildings and remnants of the city walls. $244(40 \%)$ of the 640 buildings in the area are listed as 'buildings of special architectural or historic interest', and 12\% of these have Grade 1 Listed Status.

The area experienced economic decline and physical decay over many years. From 1900, the Newcastle area was undermined economically as it lost out to industrial competitors across the globe. Since then, the regional economy and its land and property markets have struggled to sustain themselves, relative to more buoyant parts of the UK. From the 1980s, Newcastle city centre has also had to contend with a range of out-of-centre developments. Retailing declined as the city's retail centre shifted to new shopping centre developments, and office functions also moved out to new business parks. By the mid 1990s, Grainger Town had a million square feet of empty office floor space. In 1992, 47\% of the area's listed buildings were in such a poor state that they were deemed by English Heritage to be 'at risk' and a further $29 \%$ were considered 'vulnerable'. Grainger Town had an atmosphere of decline, with important historic buildings underused and decaying and the streetscape, the 'public realm', in a poor, degraded condition. In the late 1970s and in the 1980s, limited attempts had been made to tackle some of these problems, but since these were patchy and piecemeal as well as narrowly focused on building conservation, they failed to tackle underlying problems of economic decline.

In 1996, English Partnerships (now part of the Homes and Communities Agency), Newcastle City Council and English Heritage drew up proposals for a major regeneration scheme which was developed by consultants EDAW as the "Grainger Town Regeneration Strategy". The strategy, which formed the basis for the Grainger Town Project, stressed the fundamental importance of economic development and revival to support investment in the area's physical heritage. It recognised the need to strengthen and develop the retailing, office, leisure and housing functions of the area and to capitalise on its distinctiveness, environment and heritage. The strategy also formed the basis for a successful bid for SRB (Single Regeneration Budget) funding to support the Grainger Town Project, a six year scheme which started in 1997 and ended in March 2003.

The Grainger Town Project brought together funding from several public sources, including SRB (GBP 11.006 million), a major commitment of GBP 25 million from English Partnerships (subsequently One NorthEast), and funding from the City Council, English Heritage, the Heritage Lottery Fund and other sources. A key aim was to use public funding to lever-in private sector investment, encouraging the private sector to invest and arrest decline and decay. It was a comprehensive strategy, linking to broader themes of

10. The case study on the Grainger Town Project was conducted through interviews with Newcastle City Council officials and Newcastle City Centre Partnership officials as well as literature study (Robinson, 2003; Healey et al., 2002, etc.). The case study on the Otemachi-Marunouchi-Yurakucho district was conducted through literature study (Otemachi-Marunouchi-Yurakucho Redevelopment Project Council, 2008; MLIT, 2008, etc.). 
economic, social and cultural development. The vision was to make Grainger Town 'a dynamic and competitive location', with a 'high quality environment'; a place with a 'reputation for excellence...focused on leisure, culture and the arts, retailing, housing and entrepreneurial activity.'

The Grainger Town Partnership, constituted as a company limited by guarantee, was set up to oversee delivery of the Project. The Partnership Board had 20 members, including representatives from the City Council, public agencies, the private sector and urban residents. Business and Residents Forums were also established as mechanisms to foster dialogue and accountability. In addition, Advisory Panels on Urban Design and Arts and Culture were set up, which enabled the Partnership to benefit from a wider range of expertise and experience. The Project had a Delivery Team of officers, based within the area, responsible for implementing the scheme.

Figure 2.1. Structure of the Grainger Town Partnership

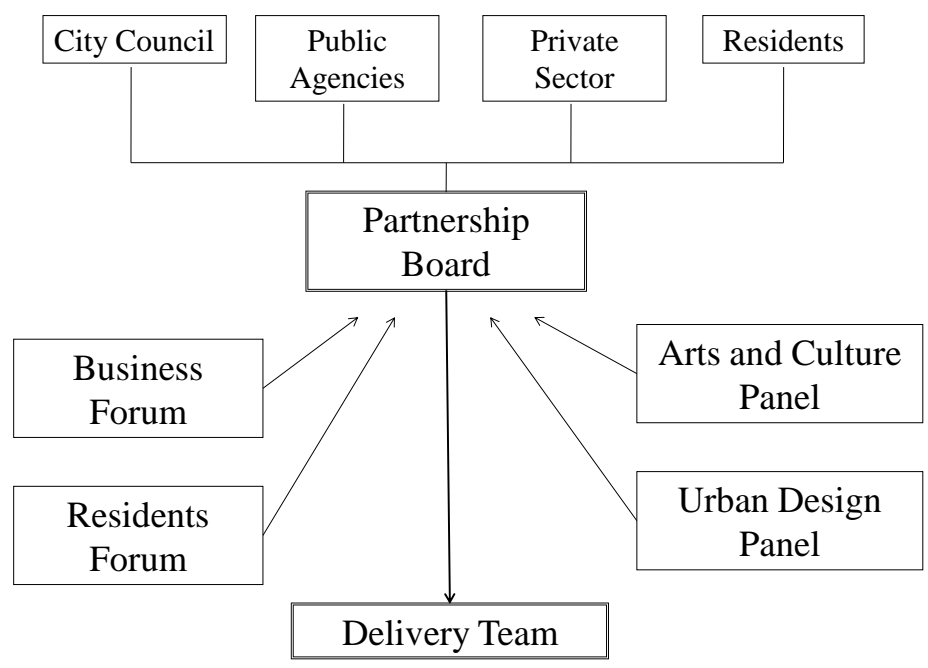

From the start, the Partnership worked to build confidence in the area, demonstrating commitment to change and to an 'ethos of quality'. Within a few years after the project started, it became visually clear that Grainger Town was undergoing real revival, and that sense of change boosted the confidence of the private sector. High-quality improvements to the public realm helped to create a critical mass to generate confidence in private owners and investors, and the Partnership developed strong relationships with the private sector. Refurbishment schemes, supported by the Project, were implemented, bringing buildings back into use for retailing, leisure, offices and residential accommodation. Latterly, the regeneration programme has also emphasised art and cultural initiatives, including public art, creative lighting and new cultural facilities. Over the past six years, the property market has steadily strengthened, Grainger Town has acquired a very positive reputation and the Partnership's successes have been acknowledged by awards for good practice and effective regeneration.

The Project achieved significant outcomes, especially in relation to physical regeneration and private sector investment. Private sector investment by March 2003 reached over GBP 145 million, almost double the original target of GBP 74 million. 121 buildings have been brought back into use, compared with a target of 70. The economic revival of Grainger Town is reflected in the growth of retail and office rental values. Retail rentals have increased significantly in the northern part of the area. After a long period of decline, there is an upward trend in employment; total employment in Grainger Town grew by $14 \%$ between 1996 and 2001. There is strong demand for residential accommodation, with housing now being provided for sale as well as for rent. 
During the last two years the Partnership drew up a Forward Strategy setting out arrangements after the end of the six year SRB scheme in March 2003. The Forward Strategy includes arrangements for completing ongoing projects, the maintenance of public realm improvements and public art works, and administrative and monitoring issues. Responsibility for ensuring implementation of projects has passed to City Council officers working with One NorthEast, and a Charter was agreed upon with the Council detailing maintenance arrangements. The Partnership Board was superseded by the City Centre panel, an advisory group set up by the City Council in 2001 to develop, manage and monitor the Council's City Centre Action Plan and comment on development proposals and city centre issues.

As well as making arrangements for the maintenance of public spaces and features, the Partnership has also sought to safeguard and promote improvements to privately owned properties. A Grainger Town Maintenance Manual has been published, which sets out planning procedures and detailed guidance on the maintenance of buildings. This is intended to ensure that improvements undertaken with the support of the Project are properly maintained, but it provides guidance for all property owners and occupiers throughout Grainger Town. The aim is to conserve historic buildings and uphold standards, so as to sustain regeneration in the future.

\section{Case Study 2: Otemachi-Marunouchi-Yurakucho District, Tokyo}

The Otemachi-Marunouchi-Yurakucho district (hereafter, the OMY district), which is located in Chiyoda Ward, the heart of metropolitan Tokyo, has functioned as the center of the Japanese economy for about 100 years with significant efforts for the area's development and management. The development of the OMY district began at the end of the 19th century as Japan's first office district. During the 1950s to 1960 s, in response to the strong demand for office buildings following Japan's economic recovery after the World War II, many developers constructed large-scale, modern office buildings in this area. Various concepts of urban landscape such as wide city blocks, integrated districts and orderly cityscape were born during this period. In the 1970s and 1980s, because of the increasing trend toward corporate globalisation and strong demand by domestic and international companies to establish an operational base in metropolitan Tokyo, enhancement of functional capacity (e.g. advanced information technology, adequate office space, etc.) and improvement of the working environment in the district became major issues for the property owners. In order to address such issues and integrally redevelop the district, the property owners established the OMY District Redevelopment Project Council (hereafter, the OMY Council) in 1988 as a forum for discussing specific city-planning proposals for the 21st century. In 1994 the OMY Council adopted the OMY Basic City-Planning Agreement as a guideline for renewing the District. The Council also reported to the Tokyo Metropolitan Government and Chiyoda Ward upon the conclusion of the agreement, as well as submitted a request for guidance and assistance in redeveloping the district.

Recognising the importance of taking specific action to promote public-private partnership in the development of the district, the Tokyo Metropolitan Government, Chiyoda Ward, the East Japan Railway Company and the OMY Council came together to establish the Advisory Committee on OMY Area Development in 1996. The committee's main objectives were to ensure that renewal of the district is coordinated among all the stakeholders, by comprehensively discussing priority issues such as the future vision of the district and the rules and methods for realising it. The results of discussions were compiled and issued as City-Planning Guidelines in 2000 (revised in 2005), which are non-regulatory, non-binding guidelines for property owners who agree to follow them when they redevelop their properties. Based on these guidelines, private and public sectors are co-operating in renewing the district. For example, a regeneration project was launched in Otemachi district in 2006, in which the property owners will renew their old buildings whereas the central government will support them by providing a land for the initial development. With the strong partnership between the public and private sector, the project amounting to USD 3.4 billion aims to renew the district with maintaining its function as a world's leading business centre. 
Enhancing the quality of the public realms based on partnership arrangements between the public and private sectors has also been a key to successful evolution of the area. The renovation of the main street pavement for newly-invited glamorous boutiques revitalised the entire area. The numbers of retailers has now almost tripled within 10 years. The district has been transformed into a highly attractive multifunctional 'Premier Place,' including various retailers, restaurants, halls, facilities for entrepreneurs and industry-academia joint-businesses.

Moreover, Mitsubishi Estate Co., Ltd., the largest property owner in the OMY district, recently decided to reconstruct the historic red-brick building, Mitsubishi Ichigokan, which was originally built in the late 19th century as the very first office building but demolished in the 1960s during Japan's rapid economic growth. The cultural and historic asset is now considered as an important factor to enhance the unique attractiveness and distinctiveness of the area.

In addition to the "hardware" aspects of city-planning, there was a heightened awareness of the need to address the "software" aspects as well, such as strengthening the city's interactive functions and enhancing the district's urban appeal to tourists. Following extensive discussions by the OMY Council, a non-profit organisation called the OMY Area Management Association was established in 2002. It works in close co-operation with the OMY Council in enhancing the environment, revitalising the area, and creating various opportunities for interaction, and actively invites the participation not only of the property owners in the district but also workers and visitors to the area (e.g. by organising area-wide art and culture events, festivals, etc.). In 2005, the association was designated as a public space utilisation organisation under the Tokyo Metropolitan Promotion Ordinance, which permits deregulation of public spaces use to enhance the uniqueness and attractiveness of urban areas, and is now actively utilising public spaces for open cafes and other applications. As a result, the area has been transformed from a monotonous office district into a versatile place with a variety of activities.

Figure 2.2. Relations among organisations for the OMY district development

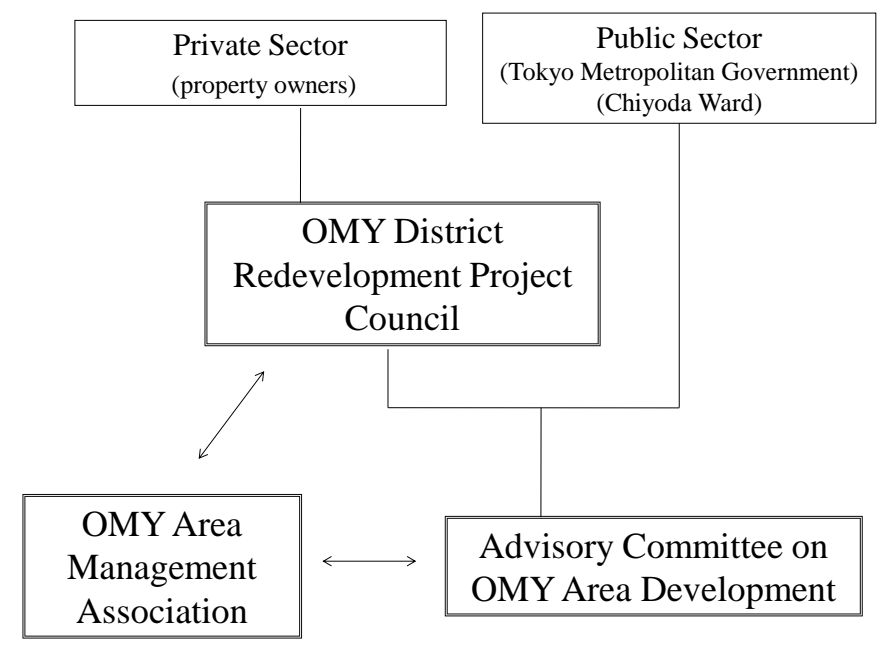

\section{Policy implications}

On the basis of the above case studies, this sub-section presents several policy implications that could form the basis for successful partnership arrangements for urban environment enhancement. 


\section{Identifying strategic targets and sharing vision among stakeholders}

One of the most relevant lessons which can be learned from the case studies is the importance of identifying strategic targets unique to the area and sharing future vision among stakeholders. ${ }^{11}$ In the case of the Grainger Town Project, the "Grainger Town Regeneration Strategy" became a very influential foundation for the development of the project, identifying unique urban assets and playing a catalytic role in building consensus among stakeholders. The report led to a shift in the emphasis of the project from the narrow conservation agenda to a broader economic development approach. Although tensions existed between the conservation perspective and property development perspective, the Grainger Town Partnership made significant efforts to share the vision with all the stakeholders through various activities such as promotional conferences and the publication of a "Heritage Handbook" which aims to promote Grainger Town as an investment location by associating the heritage of the area and quality. Both public and private actors could have a shared view of what the problems were and what solutions were necessary by subscribing to the Strategy. Thus they had a sense of common purpose and a sense of 'ownership' of the Project. In the case of the OMY district, the "City-Planning Guidelines" have played a crucial role in coordination not only among different private stakeholders but also among public and private sectors. Of course, it can be argued here that the strategies used in the cases are not applicable to all cities as these areas inherently had distinctive characters which could be potentially enhanced. However, the importance of identifying unique urban assets to share future vision among stakeholders would apply to other cases which do not have the privilege of such distinctive character.

\section{Creating critical mass to raise investor confidence}

A key focus of urban regeneration partnerships is to raise investor confidence in the area. Private sector investment is crucial to changing urban conditions in a way that can be sustained in the long-term. In this regard, it is important for the partnerships to guide public sector interventions so that they create the conditions for sustained private sector investment, in other words 'critical mass,' as the result of which private investors have confidence and are attracted to make investments in the area. In the case of the Grainger Town Project, the commitment of substantial public expenditure in the targeted area was a crucial factor in the success of the Project. By combining the financial resources of several agencies, a critical mass of funding support was made available, eventually amounting to GBP 45 million. Without that, the Project would probably have been as ineffective as the past small-scale initiatives. In particular, the significant investment in high-quality public-realm improvements was a key contributor in building confidence among private investors. High-quality public-realm works were undertaken early on in the Project, giving a clear signal about commitment to changing the area. In the case of the OMY district, the enhancement of the public realm, such as the main street pavement for newly-invited glamorous boutiques, also contributed to revitalising the entire area.

\section{Establishing an area-based, arms-length organisation for development and management}

Given that the resources, such as financial and human resources, which can be mobilised to enhance the urban environment, are limited, they must be strategically targeted so as to secure the maximum value from the inputs. As a result, an organisational arrangement dedicated to enhancing the environment of the

11. The economic rationale for sharing vision to enhance urban environment could be explained based on game theory or the concept of social dilemma. As mentioned in section two, the characteristic of the urban environment as public goods leads to a free-rider phenomenon (i.e. the rational choice of individuals is not to cooperate with others). However, by sharing the vision (i.e. payoff matrix in terms of game theory) and ensuring the commitment of all the participants' cooperation, the rational choice of individuals becomes to cooperate with others. Thus sharing vision is the most important condition in order for partnerships to work effectively (see Box 3.3). 
targeted area is crucial as a strategic vehicle to allocate limited resources. Moreover, it is argued that the benefits of creating an organisation that is at arm's length from the local authority outweigh the disadvantages (DTLR, 2001). In particular, it provides a concentrated focus and credibility with the private sector through this perceived independence. The Grainger Town Partnership was established as a separate legal entity which was effective in simplifying relationships and building mutual trust with the private sector quickly. In the case of the OMY district, the establishment of the Advisory Committee on OMY Area Development enabled limited intellectual and relational resources to be strategically allocated in the enhancement of the targeted area, which led to the issuance of the City-Planning Guidelines.

\section{Considering self-sustaining mechanisms for long-term enhancement of the urban environment}

Many of the partnerships for urban regeneration are time-limited, or at least their funding is. Although operating on a limited life basis is often important in concentrating efforts and retaining interest, sustainable management and development beyond the life of the funded partnership is needed in many cases for future enhancement of the urban environment. Thus succession strategy becomes important. At the end of the partnership life, partners tend to take one of three stances (see Box 3.3).

\section{Box 3.3. Succession strategies of partnerships}

'Keep the partnership going': Those who wish to keep a formal partnership in place after funding ceases are driven by a belief that either i) valuable relationships have been built and might perish without a formal framework; or ii) specific partnership outputs (both social and infrastructural) need managing and developing beyond the life of the funded partnership; or iii) the locality continues to have pressing social and economic needs despite the funded intervention and that a continued partnership would help to keep attention focused on the area.

'Let it die peacefully'. Those who are happy to see the partnership terminated stress the futility of trying to keep a structure and a programme going without a dedicated budget. They also suggest that being prepared to 'close up shop' is a mark of the partnership's success: the goal of regeneration work is to build capacity in the urban community and not to perpetuate dependency on the benevolence of an 'official' body. There is a suspicion that those who argue for the continuation of the partnership are engaged in organisational self-justification. Some partners are happy to see the partnership wound-up because of the burden that involvement places on local bodies and key individuals, particularly from the community and voluntary sector. Despite 'capacity building' activities, a sense of 'network fatigue' is obvious in localities coming to the end of a significant regeneration programme - people 'need a break'.

'Support what lasts'. This cluster of views represents something of a middle way. It recognises the importance of sustaining momentum in the wake of a major regeneration programme but sees the problems inherent in seeking to continue formal partnership arrangements in the absence of dedicated budgets, and in the context of 'network fatigue'. The stress here is on seeking support from mainstream local budgets (for example from the local authority, TEC, health or police) for focal points of activity in the locality, allowing co-ordination to arise from informal networks. For community-based activity such networking might be facilitated by an umbrella voluntary organisation; service-based activity could draw on existing professional and user networks.

Source : Lowndes and Skelcher (1998)

While there are diverse views and options concerning the succession or termination of partnerships, it is evident that they focus upon the importance of sustaining network-style relationships in the governance of urban regeneration. Those who favour a continuation of formal partnership arrangements do so because they see these as protecting existing and emergent networks. Those who are content to see the end of formal arrangements still recognise the centrality of networking to the future of urban regeneration in their locality, but think that formal partnerships put undue pressure on networkers and that other forms of support are more appropriate in the long term. 
At the final stage of the six-year regeneration scheme, the Grainger Town Partnership discussed the possibility of retaining the partnership and some of the staff in the Delivery Team. The Partnership had earned the trust and confidence of property market professionals, developers and businesses, and there were strong arguments in favour of retaining both the Partnership Board and at least some officer capacity. However in the event it was decided that the Project should end and that the City Council would take over most of the Partnership's functions and responsibilities for several reasons including the issue of funding. The role of the Partnership Board was superseded by the City Centre Panel, an advisory group concerned with management and development of the city centre. The Panel was transformed into the City Centre Partnership after restructuring various arrangements for managing and improving the city centre, and from April in 2009 the City Centre Partnership becomes a Business Improvement District (BID), which ensures independent financial resources for enhancement and management of the city centre. Thus stakeholders in Newcastle city centre have made efforts to keep momentum which was generated in the Grainger Town Project through various institutional arrangements after the termination of the Project.

In the case of the OMY district, in order to ensure and strengthen sustainable management of the area, various area-based organisations have worked continuously in collaboration with each other. In addition to the co-ordination by the OMY Council and the Advisory Committee on OMY Area Development to enhance the quality of the physical development in the area, the OMY Area Management Association was established as an organisation to co-ordinate sustainable area management through various activities such as organising area-wide art and culture events, festivals, etc. The recent deregulation implemented by Tokyo Metropolitan Government aiming to facilitate flexible use of public spaces enabled the Association to utilise public spaces for open cafes and other applications, which have supported the sustainable operation of the Association. Both the public and private stakeholders have been pursuing sustained enhancement of the environment of the area in close collaboration with each other. 


\section{SECTION 4: CONCLUSION}

Urban attractiveness has been increasingly regarded as a key factor for the competitiveness of cities. Following the impact of globalisation and the emergence of knowledge-based economies, enhancing urban attractiveness is now high on the agenda of urban policy in many OECD countries. A city's attractiveness is determined by a wide range of elements. The OECD report "Competitive Cities: A New Entrepreneurial Paradigm in Spatial Development" (OECD, 2007) analysed various elements contributing to urban attractiveness (e.g. flagship redevelopment, cultural facilities, international events, etc.) and made various findings such as the importance of enhancing distinctiveness by paying careful attention to the cultural and historical assets a city possesses. Indeed, many cities have begun to recognise attractive physical urban environment which enhances the uniqueness of a city, such as distinctive urban townscape and the presence of historic and natural features, as one of the important factors to differentiate themselves from other cities.

This paper has analysed the characteristics of physical urban environment as well as the barriers to its enhancement, and examined institutional arrangements to address these barriers and enhance the physical urban environment for competitiveness. On the basis of discussions in the previous sections, this section summarises key policy recommendations for enhancing physical urban environment.

\section{Key policy recommendations for enhancing physical urban environment}

\section{Identifying strategic targets and sharing vision on urban environment enhancement among stakeholders}

In many cases, an attractive urban environment is characterised as a public good. The free-rider phenomenon associated with public goods prevents each individual stakeholder from having an incentive to contribute to collective action to enhance the urban environment even though such collective action could maximise the total benefits accruing from the enhancement. The first step to avoid this situation would be to show all the stakeholders the social benefits of enhancing the physical urban environment clearly and incentivise them to make a contribution to the collective action.

Area-based organisations (e.g. urban regeneration partnerships, urban community organisations) representing local demands for urban environment and dedicated to its enhancement, and experts who raise awareness of the value of the urban environment would be key contributors in identifying unique urban assets and disseminating vision of the area and information about the benefits of enhancing the physical urban environment among stakeholders. Governments could play an important role in encouraging vision sharing and information dissemination by supporting these organisations and experts.

\section{Creating critical mass to incentivise investors to contribute to urban environment enhancement}

The urban environment is composed of various elements including not only public realms for which the public sector is mostly responsible but also private properties the quality of which the private sector, such as private property owners or investors, plays an essential role in enhancing. Thus collaborative institutional arrangements such as partnerships between public and private stakeholders are one of the essential factors for strengthening the attractiveness of the urban environment.

Private sector investment is especially crucial to building up and maintaining momentum for urban environment enhancement that can be sustained in the long-term. In this regard, the public sector has to 
play a significant role at an initial stage to incentivise sustained private sector investment by for instance intensive public investments which deliver a clear visual message to the private sector. In other words it is a key to establish 'critical mass' by which private investors have confidence in the future of the area where they are located and are attracted to make sustained investments contributing to urban environment enhancement.

Obviously, it is important that public-private partnership approaches to enhance the physical urban environment are viewed broadly - they are not just public sector investment but creating the right conditions in which the private sector wants to enhance invest in enhancing the physical urban environment because it sees it as a profitable activity in its own right. There are some examples of companies undertaking heritage-led regeneration without grant aid because they see it as good for business. Once there's a strong market it can be self-sustaining.

\section{Establishing area-based organisational mechanisms for urban environment enhancement}

Because resources, such as financial and human resources, which can be mobilised to enhance the urban environment, are limited, strategic allocation of resources to a targeted area is one of the important issues to maximising value from the inputs. As a result, an organisational arrangement dedicated to enhancing the environment of the targeted area is crucial as a strategic vehicle to allocate the limited resources. Examples include establishing area-based regeneration partnerships or companies.

If such organisational arrangements have effective governance structure, they also facilitate collective decision-making among stakeholders. For example when unanimous consent of all the stakeholders is required to make a collective decision (e.g. covenants) the negotiation costs could be prohibitive. Establishing an organisational scheme which allows stakeholders to create a legal vehicle that is managed by a board elected by the stakeholders and makes collective decisions would help facilitating collective decision-making and reducing transaction costs associated with it. Although establishing such organisational arrangements requires its own institutional costs, governments would play an important role in reducing such costs through, for example, standardising formation of such legal entities as well as various supportive activities.

\section{Considering self-sustaining mechanisms for long-term enhancement of the urban environment}

While many urban regeneration partnerships funded by public entities are often time-limited, it is essential to maintain the momentum generated through the partnership activities in order to further enhance the attractive urban environment. A key here is how to develop self-sustaining mechanisms for long-term enhancement of the area. For example, as funding is one of the biggest issues involved in the continuation of area-based organisations, it is a key to consider self-sustaining financial mechanisms for their operation. Governments could play a supportive role in promoting such mechanisms for long-term urban environment enhancement through, for instance, establishing organisational schemes which ensure independent financial resources for the partnership arrangements (e.g. Business Improvement Districts).

\section{Promoting stakeholder involvement from an early stage}

Whereas the type of public intervention can vary from regulatory instruments to voluntary visions, it is essential to promote stakeholder involvement in the decision-making process from the start. Implementing regulatory instruments without stakeholders' understanding would discourage them to support the policies and could lead to high enforcement costs. On the other hand, involvement of local community would ensure policymakers to address local needs and help to avoid gentrification and displacement, which are the typical negative effects of heritage-led regeneration. For example, requiring 
local governments to involve the local community in preparing a statutory plan helps to identify possible local tensions and how they might be overcome.

In order to promote active participation of stakeholders, it would be important to encourage their willingness to be involved in the decision-making system through, for example, enabling private stakeholders, such as property owners and investors, themselves to propose a statutory plan to local government, and promoting area-based partnership arrangements among public and private stakeholders.

To make participation work effectively, it is also important for each participant to clearly recognise the information at their disposal. It is possible that even though a party has easier access to information than other parties, it might not recognise the importance of the information (e.g. the unique value of the urban environment). In this regard, private organisations and experts, who are engaged in raising awareness of stakeholders about such information, would play a key role in distributing information. Government support for these organisations and experts would be a key in promoting participation.

\section{Gathering sufficient information necessary to decide the optimal level of public intervention}

When implementing public intervention such as regulatory instruments, one of the greatest challenges for policymakers would be to what extent governments should intervene in the private market. Gathering information necessary to decide the optimal level of intervention (e.g. the nature and degree of regulation) is crucial when implementing various policy instruments.

One of the ways to gather sufficient information from stakeholders would be to promote stakeholder participation in the decision-making process. Another measure to gather information necessary in deciding the optimal level of intervention would be to estimate the social benefits and costs accruing from the intervention as objectively as possible. Though such estimates, especially that of social benefits are somewhat difficult, a wide range of techniques have recently been developed to evaluate the benefits and costs of policy implementation, (e.g. Hedonic Pricing Method, Contingent Valuation Method, etc.). While those evaluation methods are still imprecise and costly, they could help make policymakers aware of the benefits and costs that may previously have been overlooked.

\section{Building capacities of local governments}

Finally, in order for local governments to be able to play important roles mentioned above, it is essential to have the financial and human resources. National governments are well situated in helping capacity building of local governments, by disseminating leaning and best practices among local authorities as well as by awarding financial aid to help local governments delivering policy framework to enhance physical urban environment. Another interesting scheme for capacity building is sharing resources. For example, some local authorities may pool their resources with neighbouring places to pay for specialist architectural advisors to provide a service for several local authorities which they otherwise could not afford individually. 


\section{ANNEX A: MODELS TO ANALYSE INSTITUTIONAL ARRANGEMENTS FOR URBAN ENVIRONMENT ENHANCEMENT}

There are a wide range of theoretical models applicable in analyzing policies to enhance the urban environment. We observe here an analytical framework based on property rights theory and transaction cost economics, which would be conducive to the comparative analysis of various institutional arrangements for urban environment enhancement.

To simplify the discussion we will assume two parties: a community (e.g. a group of residents or businesses who live in a given area) and a developer who plans a development on his property in the community. (We assume here the externality in question is a matter at the community level (e.g. districtlevel landscape, etc.). If the externality is a matter at the city level, the former party could be the city government instead of the community.)

We will also assume that the development can be characterised on a scale which we shall call the specification of the project and that the external effects of the development (i.e. externalities) on the environment of the community are a function of the development's specification, the increases of which bring about successive increases in the level of positive externalities (or decreases in the level of negative externalities) it generates. The marginal benefit to the community of each specification for the project will be the monetary value of the marginal increase in positive externalities (or the marginal decrease in negative externalities) it brings about. We will refer to this as the marginal benefit to the community with a given specification. This is shown in Figure A1 as a monotonically decreasing function of specification. The marginal benefit to the community is positive at any specification other than $\mathrm{O}$ and further benefits are obtained at higher specifications. These represent net gains to the community from the development which may take the form of physical benefits such as co-ordinated architectural design, preserved historic features, increased natural amenities, etc. (or fiscal benefits such as contributions to the local authority). Such marginal benefits are assumed monotonically decreasing in Figure A1.

The social cost of increased specification is the reduction in the developer's profits. In Figure A1 this is illustrated by the monotonically increasing marginal cost to the developer curve. The developer's profitmaximising specification is designated $\mathrm{O}$. Any specification other than $\mathrm{O}$ reduces the developer's profits. It is assumed in Figure A1 that the more specification is imposed on the developer the more marginal cost the developer incurs. Socially optimal specification is described as $\mathrm{S}^{*}$ where the social net benefit (i.e. the benefit to the community minus the cost to the developer) is maximised. 


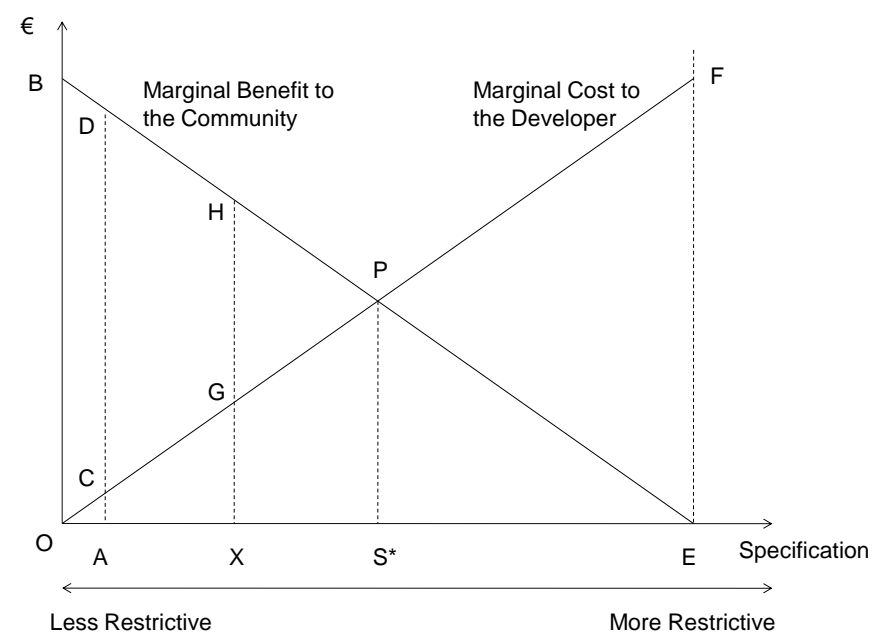

According to the Coase theorem, externalities can be internalised through voluntary transactions by individual parties under several assumptions (i.e. the property rights are well defined and enforceable, there are no transaction costs including negotiation costs, information costs, and other costs in exchanging property rights, etc.), since the producer and consumer of the externality have a market incentive to negotiate a mutually beneficial trade (Coase, 1960). The Coase theorem also states that the outcome of this trading process would be the same irrespective of the initial allocation of property rights (i.e. whether it was the producer or the consumer of the externality who held the property rights). For instance, if the initial property rights are assigned to the developer, the negotiation will start from $\mathrm{O}$. If the specification increases by OA, the community will receive a benefit equal to the area OADB. Therefore, the community has an incentive to negotiate with the developer to increase the specification by $\mathrm{OA}$ in exchange for compensation less than the area OADB. On the other hand, since the developer will incur a cost equal to the area OAC with the specification increase by OA, he also has an incentive to negotiate with the community to accept the specification increase in exchange of rewards more than the area OAC. Therefore a deal can be made between the two parties with the community paying compensation equal to the area between OAC and OADB to the developer. This transaction will continue to be made until it reaches the specification $\mathrm{S}^{*}$ which is the socially optimal allocation. Likewise if the initial property rights are assigned to the community (assume it is E), the negotiation will start from $\mathrm{E}$ and will continue until it reaches point $S^{*}$. Thus under the above-mentioned assumptions the specification finally will be settled upon the unique and economically efficient point $S^{*}$ regardless of the initial distribution of entitlements.

\section{Transaction costs}

In the Coase theorem, besides the well-defined and enforceable property rights assumptions, it is assumed that property rights are transferable from one party to another without any transaction costs. The real world, however, differs from that assumed in the theorem in that there are a wide range of transaction costs in exchanging property rights (Ellickson, 1973; Fischel, 1985; Lai, 1994; Sorensen, 1994; Cooter, 1997).

\section{The composition of transaction costs}

Transaction costs have been defined in various ways. Coase (1937) defined transaction costs using the price mechanism, which include the cost of discovering relevant prices and of negotiating and concluding contracts. According to Williamson (1985), there are two kinds of transaction costs: (1) ex ante costs of 
drafting, negotiating, and safeguarding an agreement, (2) ex post costs of haggling, governance, and bonding to secure commitments. In the context of policies to enhance the urban environment, ex ante costs can be divided into 'information costs' and 'negotiation costs', whereas ex post costs might refer to 'enforcement costs'.

\section{Information Costs}

The urban environment is characterised as a public good, which can be enjoyed by additional people without reducing the consumption of others. This means, in the above-mentioned model, that a community's willingness to pay for property rights for a certain specification is the result of a vertical summation of each member's willingness to pay for the specification. (The marginal benefit to the community is derived from the sum of individual benefits D1, D2, D3, etc. in Figure A2.) One problem of public goods is to get people to reveal their willingness to pay for them so as to provide the optimal amount. Because everyone gets the same amount regardless of contribution, the temptation is to understate one's preferences, thus becoming a "free rider". Because of the free rider problem, the optimal level of supply could not be achieved.

Figure A2. Marginal benefit to the community

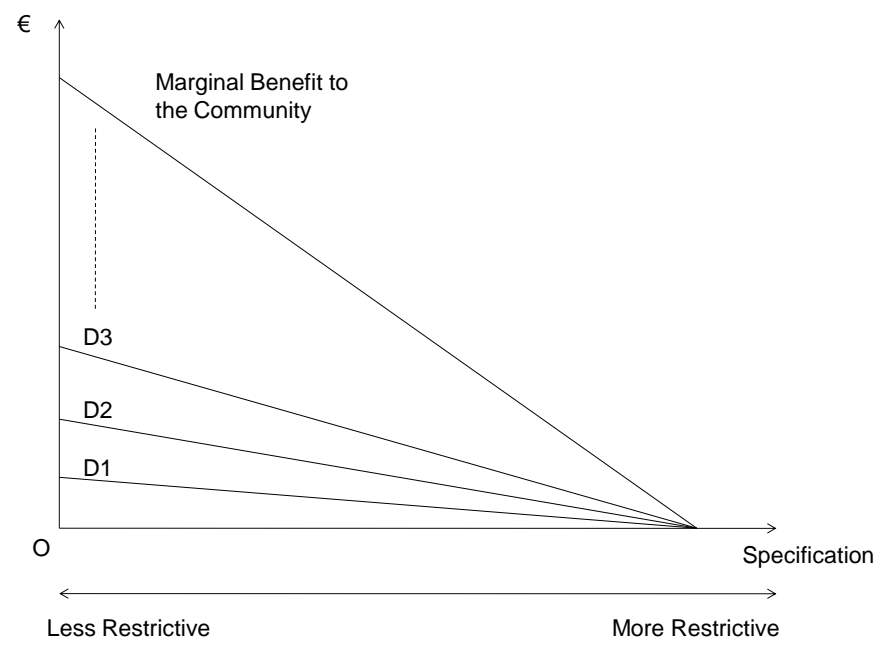

In addition to the free rider problem, it is possible that the members of the community do not recognise the value of the environment and cannot express their exact willingness to pay for it. Moreover, even if the community recognises the value of the environment and can express their willingness to pay for it, their preferences can change over time. In the model, this means the shift of the community's marginal benefit schedule and the equilibrium from, for example, $\mathrm{S}^{*}$ to $\mathrm{X}^{*}$ in Figure A3. If the supply of the urban environment is flexible enough to adjust to the change of people's preferences, there would not be any problems. However, because of its characteristic as an irreversible good, once it is established or eliminated, it would be difficult to adjust to new preferences. 
Figure A3. The effect of changes in people's preferences for the urban environment

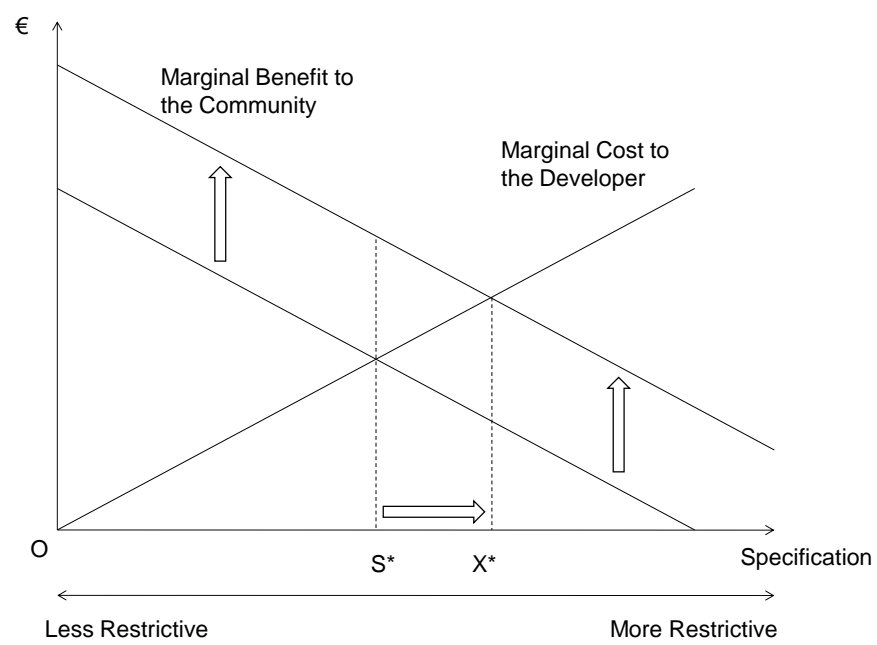

Negotiation Costs

Negotiation costs arise when strategic bargaining might prevent, or at least inefficiently delay, the mutually advantageous exchange of property rights. In Figure A1, if the initial property rights are assigned to the community (i.e. point E), the community would accept as little as the compensation equal to area EPS* to allow specification decreases to point $\mathrm{S}^{*}$. The developer, however, would be willing to pay up to the amount equal to area EFPS* to obtain this privilege. There is latitude for bargaining here, and the strategies and delays caused by taking various bargaining positions might lead to some result other than $\mathrm{S}^{*}$, which was deemed most desirable.

\section{Enforcement Costs}

Enforcement costs refer to the costs associated with monitoring the agreement made by parties and taking the actions necessary to make sure that each party fulfills the agreement. In the case of private agreements such as contracts, if the terms of the contract were breached by one party, the other party would appeal to the court. Therefore the costs include that of maintaining the court system. In the case of public intervention such as zoning regulations, the public agency would monitor whether the regulations are followed and take necessary actions if the regulations are not followed. In this case, the cost includes the administrative cost burden imposed on the public authorities responsible for applying the policy instruments such as regulations.

\section{Dimensions of transactions}

According to the transaction costs approach, the variety of ways of organising transactions found in the world reflects the fact that transactions differ in some basic attributes. The key dimensions affecting the nature of any transaction are as follows (Milgrom and Roberts, 1992):

- the specificity of the investments required to conduct the transaction

- the frequency with which similar transactions occur and the duration or period of time over which they are repeated

- the complexity of the transaction and the uncertainty about what performance will be required 
- the difficulty of measuring performance in the transaction

- the connectedness of the transaction to other transactions involving other people

The more specific the investments or assets required for a transaction the more likely it is that the transaction will take place through a long-term contracting arrangement or a hierarchy rather than a market. If a transaction occurs frequently and over an extended period of time it means that market transactions are likely to be less favoured. The more complex and uncertain a task, the more likely it is that the transaction will take place within some form of hierarchy. As the difficulty of measuring performance increases, the likelihood of relying on markets to govern a transaction declines. The more a particular transaction is connected with transactions which involve other people, the more difficult it is to govern the transaction through a market mechanism and ensure that the other party to the transaction delivers what is required.

In the context of policies to enhance the urban environment, asset specificity is particularly important. Because the urban environment is a location-specific good, investments by each individual stakeholder to contribute to its enhancement are meaningful only in the area in which the investments occur. In other words, the investment is 'locked-in' the area. Thus investors may have suboptimal incentives to make location-specific investments, because there is a possibility that the investments cannot be fully recouped in certain situations.

\section{Criteria for the analysis of institutional arrangements}

In order to analyse the strengths and weaknesses of various institutional arrangements, it would be meaningful to set up several criteria. ${ }^{12}$

\section{Social Benefits: Increases in Positive Externalities (Decreases in Negative Externalities)}

With regards to urban environment issues, the direct policy goal is to enhance the quality of the urban environment by for instance strengthening the unique characteristics of a given area. Therefore the first criteria should be how much the institutions contribute to enhancement of the quality of the urban environment, in other words, how much positive externalities (negative externalities) the institutions increase (decrease). In Figure A1, if the institutional arrangements could achieve specification $S^{*}$, the social benefits (increases (decreases) in positive externalities (negative externalities) in the community) would be equal to area OBPS*.

\section{Social Costs: Costs to Increase Positive Externalities (Costs to Decrease Negative Externalities)}

When introducing new institutional arrangements or changing existing ones, policymakers need to take into account not only the benefits accruing from the institutions but also the costs of implementing them. These costs include not only direct costs (e.g. increases in construction costs) but also indirect costs such as opportunity costs (e.g. decreases in potential development rights). In Figure A1, if the institutional arrangements aim to achieve specification $\mathrm{S}^{*}$, the developer would have to incur costs equal to area OPS*.

12. The criteria discussed here are based on previous studies on land-use control from property rights perspective such as Ellickson (1973). Although there are two basic standards in economic evaluation of public policies - efficiency and equity, we discuss here only efficiency aspects, because the issue of equity requires political judgments and persuasive arguments about equity issues are hard to construct. 


\section{Transaction Costs}

As mentioned above, there is a wide range of transaction costs associated with exchanging property rights in the market: information costs, negotiation costs, and enforcement costs. Even if the social benefits of implementing a certain policy instrument are large and its social costs are low, the instrument would not be justified if the transaction costs accruing from the policy instrument are burdensome. For instance, in Figure A1, if the institutional arrangements could achieve the specification $\mathrm{S}^{*}$, but the transaction costs are almost equal to area OBP, the total net benefits (i.e. social benefits - social costs - transaction costs) are nearly zero. Meanwhile, if the institutional arrangements could just achieve the specification $X$, but if the transaction costs are nearly zero, the net benefits would be equal to area OBHG. Thus the latter case would be more desirable than the former one in terms of the amount of the total net benefits. 


\section{BIBLIOGRAPHY}

Abelson, P. and Domin, C. (2001), Economics of Heritage Listings, New South Wales Heritage Office.

Alexander, E.R. (2001), “A Transaction-Cost Theory of Land Use Planning and Development Control”, Town Planning Review, 72(1).

Ashworth, G.J. (2002), "Conservation Designation and the Revaluation of Property: the risk of heritage innovation", International Journal of Heritage Studies 8(1).

Bailey, N. (1995), Partnership Agencies in British Urban Policy, UCL press, London.

Ball, M., Le Ny, L. and Maginn, P.J. (2003), "Synergy in Urban Regeneration Partnerships: Property Agent's Perspectives", Urban Studies 40 (11).

Bradach, J.L. and Eccles, R.G. (1991), "Price, Authority and Trust: from ideal types to plural forms" in Thompson, G., Frances, J., Levacic, R. and Mitchell, J. (1991), Markets, Hierarchies and Networks: the co-ordination of social life, Sage, London.

Brooks, C., Cheshire, P., Evans, A. and Stabler, M. (1998), "The Economics and Social Value of the Conservation of Historic Buildings and Areas: Economics of Conservation", Evaluation of the Built Environment for Sustainability.

Brueckner, J. K., Thisse, J. F., and Zenou, Y. (1999), Why is Central Paris Rich and Downtown Detroit Poor? An Amenity-based Theory, European Economic Review, Vol. 43.

Buitelaar, E. (2007), The Cost of Land Use Decisions: applying transaction cost economics to planning \& development, Blackwell, Oxford.

Buitelaar, E. and Needham, B (2007), "Property Rights and Private Initiatives: An Introduction”, Town Planning Review, 78(1).

Carmona, M., de Magalhaes, C. and Edwards, M. (2002), “What Value Urban Design?”, Urban design international 7.

Chester City Council (2002), Chester's Local Distinctiveness Strategy.

CABE (Commission for Architecture and the Built Environment) (2000), By Design: Urban Design in the Planning System - towards Better Practice.

CABE (Commission for Architecture and the Built Environment) (2001a), The Value of Urban Design.

CABE (Commission for Architecture and the Built Environment) (2001b), Better Places to Live by Design: a Companion Guide to PPG3. 
CABE (Commission for Architecture and the Built Environment) (2006), Mapping Value in the Built Urban Environment.

CABE (Commission for Architecture and the Built Environment) (2007), Paved with Gold: the Real Value of Good Street Design.

Coase, R.H. (1937), “The Nature of the Firm”, Economica, Vol. 4, No. 16.

Coase, R.H. (1960), "The Problem of Social Cost”, Journal of Law and Economics 3.

Cooter, R.D. and Ulen, T.S. (1997), Law and Economics, Addison Wesley, New York.

Coulson, N.E. and Leichenko, R.M. (2004), "Historic Preservation and Neighbourhood Change", Urban Studies 41 (8).

Cullingworth, B. and Caves, R.W. (2003), Planning in the USA, Second Edition, Routledge, New York.

Cullingworth, B. and Nadin, V. (2006), Town and Country Planning in the UK, Fourteenth Edition, Routledge, New York.

Davis, O.A. and Whinston, A.B. (1961), "The Economics of Urban Renewal”, Law and Contemporary Problems 26(2).

DCLG (Department of Community and Local Government) (2008), Managing Town Centre Partnerships: A guide for practitioners.

DCMS (Department for Culture, Media and Sport) (2004), Culture at the Heart of Regeneration.

DTLR (Department for Transport, Local Government and the Regions) (2000), Multi-Criteria Analysis Manual.

DTLR (Department for Transport, Local Government and the Regions) (2001), Urban Regeneration Companies (URCs) - Learning the Lessons.

Diamond, D.B. and Tolley, G.S. ed. (1982), The Economics of Urban Amenities, Academic Press, New York.

Duerksen, C.J. (1986), Aesthetics and Land-Use Controls, American Planning Association, Chicago.

Duerksen, C.J. and Goebel, R.M. (1999), Aesthetics, Community Charter, and the Law, American Planning Association, Chicago.

EFTEC (Economics for the Environment Consultancy) (2005), Valuation of the Historic Environment.

Ellickson, R.C. (1973), “Alternatives to Zoning: Covenants, Nuisance Rules, and Fines as land Use Controls", The University of Chicago Law Review, Volume 40, Number 4.

English Heritage (2005), Retail Development in Historic Areas.

English Heritage (2006), Heritage Works: the Use of Historic Buildings in Regeneration.

European Commission (1999), European Spatial Development Perspective. 
Evan Stake, J. (1999), "Decomposition of Property Rights”, Encyclopedia of Law and Economics, I Private Property.

Field, B.C. and Field, M.K. (2006), Environmental Economics: an Introduction, McGraw-Hill/Irwin, New York.

Fischel, W.A. (1985), The Economics of Zoning Laws: A Property Rights Approach to American Land Use Controls, The Johns Hopkins University Press, Baltimore and London.

Fischel, W.A. (1999), “Zoning and Land Use Regulation”, Encyclopedia of Law and Economics, II Common Property and Regulation of the Environment.

Gao, X. and Asami, Y. (2001), "The External Effects of Local Attributes on Living Environment in Detached Residential Blocks in Tokyo", Urban Studies 38(3).

Gao, X. and Asami, Y. (2007), "Effect of Urban Landscapes on Land Prices in Two Japanese Cities", Landscape and Urban Planning 81.

Geuting, E. (2007), "Property Governance and Property Development”, Town Planning Review, 78(1).

Harvey, D. (1989), "From Managerialism to Entrepreneurialism: The Transformation in Urban Governance in Late Capitalism", Geografiska Annaler. Series B, Human Geography, Vol. 71, No. 1

Harvey, J. and Jowsey, E. (2004), Urban Land Economics, Palgrave Macmillan, New York.

Healey, P., Magalhaes, C., Madanipour, A. and Pendlebury, J. (2002), Shaping City Centre Futures: Conservation, Regeneration and Institutional Capacity, University of Newcastle, Newcastle upon Tyne.

Hodge, I. (1994), "Rural Amenity: Property Rights and Policy Mechanisms", The Contribution of Amenities to Rural Development, OECD publication, Paris.

Houstoun, L.O. (1997), BIDS: Business Improvement Districts, Urban Land Institute, Washington.

Hoyt, L. (2006), "Importing Ideas: the Transnational Transfer of Urban Revitalisation Policy", International Journal of Public Administration 29.

Izumi, H. (2002), Characteristics of City Planning Systems for Increasing Total Floor Area Ratio and an Analysis on Increment of Land Assets Value through Executing District Planning etc., Shinzansha, Tokyo

Kanemoto, Y (1980), Theories of Urban Externalities, North-Holland, Amsterdam.

Kim, S.B. (2005), "Optimal Governance Mechanisms of Land Use Decisions: a Property Rights Perspective", International Society for New Institutional Economics 2005.

Lai, L.W.C. (1994), "The Economics of Land-Use Zoning: a Literature Review and Analysis of the Work of Coase", Town Planning Review, 65(1).

Lehtovuori, P. and Schmidt-Thome, K. (eds.) (2007), Economics and Built Heritage, Seminar proceedings. 
Leichenko, R.M., Coulson, N.E. and Listokin, D. (2001), "Historic Preservation and Residential Property Values: An Analysis of Texas Cities", Urban Studies 38 (11).

Listokin, D., Listokin, B. and Lahr, M. (1998), "The Contributions of Historic Preservation to Housing and Economic Development”, Housing Policy Debate (9)3.

Lowndes, V. and Skelcher, C. (1998), "The Dynamics of Multi-Organizational Partnerships: An Analysis of Changing Modes of Governance", Public Administration, Vol. 76.

Mason, R. (2005), "Economics and Historic Preservation: A Guide and Review of the Literature, Brooking Institution.

Mayntz, R. (1993), "Governing failures and the problems of governability: some comments on a theoretical paradigm', in Kooiman, J. (ed.) (1993), Modern governance, Sage, London.

Milgrom, P. and Roberts, J. (1992), Economics, Organization and Management, Prentice Hall.

Mills, E.S. and Hamilton, B.W. (1994), Urban Economics, Harper Collins, New York.

MLIT (Ministry of Land, Infrastructure, Transport and Tourism) (2008), "Enhancing Attractiveness of Japanese Cities", presented at the $10^{\text {th }}$ session of the Working Party on Territorial Policy in Urban Areas.

Nasar, J.L. and Grannis, P. (1999), "Design Review Reviewed: A Comparison of Administrative versus Discretionary Design Review", Journal of the American Planning Association 65 (4).

Navrud, S. and Ready, R.C. (eds.) (2002), Valuing Cultural Heritage, Edward Elgar, Cheltenham and Northampton.

Needham, B and de Kam. G. (2004), "Understanding How Land is Exchanged: Co-ordination Mechanisms and Transaction Costs", Urban Studies, 41(10).

Needham, B (2006), Planning, Law and Economics, Routledge, London and New York.

OECD (1999), Cultivating Rural Amenities: An Economic Development Perspective.

OECD (2000), Valuing Rural Amenities.

OECD (2007), Competitive Cities: A New Entrepreneurial Paradigm in Spatial Development.

ODPM (Office of the Deputy Prime Minister) (2004a), The Role of Historic Buildings in Urban Regeneration.

ODPM (Office of the Deputy Prime Minister) (2004b), Competitive European Cities: Where do the Core Cities Stand?

ODPM (Office of the Deputy Prime Minister) (2005), Planning Policy Statement 1: Delivering Sustainable Development.

Otemachi-Marunouchi-Yurakucho Redevelopment Project Council (2008), Otemachi-MarunouchiYurakucho Redevelopment Project Council. 
Ouchi, W.G. (1991), "Market, Bureaucracies and Clans" in Thompson, G., Frances, J., Levacic, R. and Mitchell, J. (1991), Markets, Hierarchies and Networks: the co-ordination of social life, Sage, London.

Pearce, D., Markandya, A. and Barbier, E. (1989), Blueprint for a Green Economy, Earthscan, London.

Pearce, D. and Barbier, E. (2000), Blueprint for a Sustainable Economy, Earthscan, London.

Punter, J. and Carmona, M. (1997), The Design Dimension of Planning, E \& FN Spon, London.

Renard, V. (2007), "Property Rights and the 'Transfer of Development Rights"', Town Planning Review, $78(1)$.

Robinson, F. (2003), Pride of Place: The Final Assessment of the Grainger Town Project.

Ryan, B.D. and Weber, R. (2005), Does Urban Design Influence Property Values in High-Poverty Urban Neighborhoods?, Lincoln Institute of Land Policy Working Paper.

Scottish Enterprise (2002), Streetscapes: Their Contribution to Wealth Creation and Quality of Life.

Segeren, A., Verwest, F., Needham, B. and Buitelarr, E. (2007), “(Re-)designing Markets for Land Use Decisions", Town Planning Review, 78(1).

Shibata, H. and Shibata, A. (1988), Public Economics, Toyokeizaishinposha, Tokyo.

Sorensen, T. (1994), "Further Thoughts on Coasian Approaches to Zoning: A Response to Lai Wai Chung", Town Planning Review, 65(2).

Schelling, T. (1978), Micromotives and Macrobehavior, W.W.Norton, New York.

Stephen, F.H. (1987), "Property Rules and Liability Rules in the Regulation of Land Development: An Analysis of Development Control in Great Britain and Ontario", International Review of Law and Ecnomics 7.

Streek, W. and Schmitter, P. (1985), Private Interest Government, Sage, London.

Strong, A.L. (1983), "Easements as a Development Control in the United States”, Landscape Planning 10.

Storper, M. and Manville, M. (2006), "Behaviour, Preferences and Cities: Urban theory and urban Resurgence", Urban Studies, 43(8).

Symes, M. and Steel, M. (2003), "Lessons from America: The Role of Business Improvement Districts as an Agent of Urban Regeneration", Town Planning Review, 74(3).

Thompson, G., Frances, J., Levacic, R. and Mitchell, J. (1991), Markets, Hierarchies and Networks: the coordination of social life, Sage, London.

Turner, R.K., Pearce, D and Bateman, I. (1993), Environmental Economics: An Elementary Introduction, The Johns Hopkins University Press, Baltimore.

US Department of the Interior, (2003), Historic Preservation Easements. 
Webster, C. and Lai, L.W.C. (2003), Property Rights, Planning and Markets, Edward Elgar, Cheltenham and Northampton.

Williamson, O. (1985), The Economic Institutions of Capitalism, Free Press, New York. 